\title{
Changes in Cell Structure, Morphology and Activity of Streptomyces venezuelae during the Growth, Shocking and Jadomycin Production Stages
}

\author{
Marianne S Brooks*, Tracey J Burdock, Abdel E Ghaly and Deepika Dave
}

Department of Process Engineering and Applied Science, Faculty of Engineering, Dalhousie University, Halifax, Nova Scotia, Canada

\begin{abstract}
Streptomyces venezuelae have the ability to synthesize a group of novel benzoxazolophenanthridine antibiotics called jadomycin. The aim of the study was to investigate the changes in activity, cell structure and morphology of Streptomyces venezuelae while subjected to different environmental conditions during the growth, ethanol shocking, and jadomycin production stages. The activity of $S$. venezuelae was measured using the triphenyl tetrazolium chloride (TTC) technique while the microbial population was measured using the optical density and plate count techniques. Samples from each stage were viewed under the scanning electron microscope (SEM) and transmission electron microscope (TEM). The specific TF yield was calculated by dividing the TF yield by the number of cells. The specific TF yield remained constant at $2.44 \times 10^{-8}(\mu \mathrm{mol} / \mathrm{CFU})$ during the growth period in nutrient rich medium and decreased to $0.25 \times 10^{-8} \mu \mathrm{mol} / \mathrm{CFU}$ and $0.28 \times 10^{-8} \mu \mathrm{mol} / \mathrm{CFU}$ during the acclimatization to the nutrient deprived-amino acid rich production medium and after shocking and then increased to $3.67 \times 10^{-8} \mu \mathrm{mol} / \mathrm{CFU}$ during jadomycin production. The ethanol shock did not cause $100 \%$ of the cells to change their morphology. Remarkable changes were observed in the morphology and structure (cell diameter, vacuoles present and septation/sporulation) of $S$. venezuelae during the four consecutive stages (growth, acclimatization, shocking and jadomycin production). The elemental analysis provided information for verifying jadomycin B purity $(97.86 \%)$. However, it was not possible to detect jadomycin B within cells. It is probable that jadomycin was produced outside the cells by extracellular enzymes as opposed to intracellularly by the uptake of isoleucine and glucose. The white pellets (cells), obtained by centrifugation of production medium, supports the idea that jadomycin B is produced outside the cells as jadomycin is highly coloured compound. It is also possible that the cells were highly efficient at excreting the secondary metabolites. These hypotheses need further investigation.
\end{abstract}

Keywords: Dehydrogenase activity; Triphenyl tetrazolium chloride (TTC); Jadomycin; Scanning electron microscopy (SEM); Transmission electron microscopy (TEM); Streptomyces venezuelae; Structure; Morphology

\section{Introduction}

The actinomycete Streptomyces venezuelae are capable of producing secondary metabolites such as jadomycin and chloramphenicol (Figure 1) [1]. Jadomycins have demonstrated antibacterial, antitumor, antifungal, enzyme inhibitory as well as cytotoxic properties to cancer cells [2]. All these properties make jadomycins promising novel antibiotic and cancer treatment drugs [3]. The production of jadomycins takes place in a nutrient-deprived amino acid rich medium. This can be achieved after the exhaustion of carbon, nitrogen or phosphate from the growth medium and the addition of amino acids and is induced by environmental shock using ethanol or heat [4]. The formation of the cyclized product of jadomycin is due to the presence of amino acids in the culture medium which has a biosynthetic aldehyde precursor that generates a reactive aldimine to form jadomycin [5]. The production yield of jadomycin has been extensively linked to the mass of vegetative cells of Streptomyces venezuelae that is transferred from the growth medium to production medium [6].

Dehydrogenase activity measurement can be used for the determination of bacterial growth and metabolism [7]. The test is based on the principle that the dehydrogenase enzymes are produced by all living cells and the extent to which the enzymes oxidize organic matter can be related to the number of living cells and their activities [8]. The dehydrogenase enzymes transport electrons and a hydrogen atom from an oxidized matrix to an electron acceptor $[9,10]$, and the dehydrogenase activity can be measured using the colourless triphenyl tetrazolium chloride (TTC) salt as a hydrogen acceptor which turns to a red triphenyl formazan (TF) dye after the oxidization of organic matter [11,12] as shown in Figure 2.

The purpose of this study was to evaluate the activity, morphology and structure of $S$. venezuelae during the growth, shocking and jadomycin production stages and determine the purity of jadomycin produced.

\section{Materials and Method}

\section{Chemicals and reagents}

Triphenyl tetrazolium chloride (TTC) salt was used to prepare TTC-glucose solution for measuring the dehydrogenase activity of $S$. venezuelae cells. Tris(hydroxymethyl)aminomethane and $\mathrm{NaOH}$ were used to prepare the Tris buffer solution to control the $\mathrm{pH}$ of the samples. Triphenyl formazan (TF) was used to establish standard curves for TF concentration versus absorbance and TF yield versus cell number,

*Corresponding author: Marianne S Brooks, Associate Professor, Departmen of Process Engineering and Applied Science, Dalhousie University, Halifax, Nova Scotia, Canada B3J 2X4, Tel: (902) 494-6482; Fax: (902) 420-7639; E-mail: Su-Ling.Brooks@dal.ca

Received March 22, 2012; Accepted April 21, 2012; Published April 25, 2012

Citation: Brooks MS, Burdock TJ, Ghaly AE, Dave D (2012) Changes in Cell Structure, Morphology and Activity of Streptomyces venezuelae during the Growth, Shocking and Jadomycin Production Stages. J Microb Biochem Technol 4: 063075. doi:10.4172/1948-5948.1000073

Copyright: (c) 2012 Brooks MS, et al. This is an open-access article distributed under the terms of the Creative Commons Attribution License, which permits unrestricted use, distribution, and reproduction in any medium, provided the original author and source are credited 
<smiles>CCC(C)C1C(=O)OC2c3cc(C)cc(O)c3C3=C(C(=O)c4cccc(OC5CC(O)C(O)C(C)O5)c4C3=O)N21</smiles><smiles>O=C(N[C@@H](CO)[C@H](O)c1ccc([N+](=O)[O-])cc1)C(Cl)Cl</smiles>

(a) Jadomycin B

(b) Chloramphenicol

Figure 1: Chemical structures of Streptomyces venezuelae metabolites

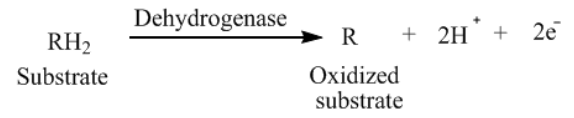

$$
2 \mathrm{H}^{+}+\left[\mathrm{C}_{6} \mathrm{H}_{5} \mathrm{C}_{\text {Triphenyl tetrazolium chloride (TTC) }} \longrightarrow \mathrm{HCl}+\mathrm{C}_{6} \mathrm{C}_{5} \mathrm{C}_{\mathrm{N}}^{\mathrm{N}}=\mathrm{C}_{\mathrm{N}}^{\mathrm{N}-\mathrm{C}_{6} \mathrm{H}_{5}}\right.
$$

Figure 2: Role of dehydrogenase in the reduction of triphenyl tetrazolium chloride (TTC) to triphenyl formazan (TF).

respectively. Methanol was used to extract the TF from the cells and ethanol was used to cause an environmental shock to $S$. venezuelae in order to induce jadomycin B production. The Tris(hydroxymethyl) aminomethane, 2,3,5-triphenyl formazan (TF), and 2,3,5-triphenyl tetrazolium chloride (TTC) were obtained from Sigma-Aldrich (Oakville, Ontario, Canada). Ethanol, methanol, glucose and $\mathrm{NaOH}$ were obtained from the Tupper Building Stores at Dalhousie University (Halifax, Nova Scotia, Canada).

The 2,3,5-triphenyl tetrazolium chloride (TTC)-glucose solution was prepared by adding $1 \mathrm{~g}$ glucose and $2 \mathrm{~g}$ TTC into a $100 \mathrm{~mL}$ volumetric flask and bringing the volume to $100 \mathrm{~mL}$ with distilled water. The TTC-glucose solution was stored in the dark at $4^{\circ} \mathrm{C}$. The Tris(hydroxymethyl)aminomethane buffer solution was prepared by adding $6.0 \mathrm{ml}$ of Tris and $20 \mathrm{~mL} 1 \mathrm{~N} \mathrm{NaOH}$ into a $1 \mathrm{~L}$ beaker and bringing the volume to $1 \mathrm{~L}$ with distilled water.

\section{Bacteria}

An initial starter plate of Streptomyces venezuelae ISP5230 was obtained from the Jakeman Laboratory, College of Pharmacy, Dalhousie University (Halifax, Nova Scotia, Canada) and stored at $4^{\circ} \mathrm{C}$. Further maltose-yeast extract-malt extract (MYM) agar plates were prepared and streaked with S. venezuelae when needed. The life cycle of Streptomyces is shown in Figure 3.

\section{Growth media}

A maltose-yeast extract-malt extract (MYM) agar and broth were used to cultivate Streptomyces venezuelae. The composition of MYM agar and broth are shown in Table 1. The various chemical components of the media were obtained from Fisher Scientific (Ottawa, Ontario, Canada).

Maltose-yeast extract-malt extract (MYM) agar was prepared by adding $4 \mathrm{~g}$ maltose, $4 \mathrm{~g}$ yeast extract, $10 \mathrm{~g}$ malt extract, $1.9 \mathrm{~g}$ MOPS buffer, and $15 \mathrm{~g}$ agar into a $1 \mathrm{~L}$ vessel and bringing the total volume to $1 \mathrm{~L}$ with distilled water. The contents were dissolved using a heating/ stirring plate (Model 310T, Fisher Scientific, Ottawa, Canada). Aliquots of $175 \mathrm{ml}$ were added to $250 \mathrm{ml}$ flasks. The flasks were plugged with a foam cap, covered with aluminum foil and autoclaved (SterileMax, Harvey/Barnstead International of Thermo Fisher Scientific, Ottawa, Ontario, Canada) on the liquid setting $\left(121^{\circ} \mathrm{C}, 20 \mathrm{~Pa}\right)$ for 15 minutes. The autoclaved flasks were stored at $65^{\circ} \mathrm{C}$ to prevent solidification of agar until used to prepare agar plates.

Maltose-yeast extract-malt extract (MYM) broth was prepared by adding $4 \mathrm{~g}$ maltose, $4 \mathrm{~g}$ yeast extract, $10 \mathrm{~g}$ malt extract, and $1.9 \mathrm{~g}$ MOPS buffer into a $1 \mathrm{~L}$ vessel and bringing the total volume to $1 \mathrm{~L}$ with distilled water. The contents were dissolved using a heating/ stirring plate (310T, Fisher Scientific, Ottawa, Canada). Aliquots of $175 \mathrm{~mL}$ were added to $250 \mathrm{~mL}$ flasks. The flasks were plugged with foam caps, covered with aluminum foil, and autoclaved (SterileMax, Harvey/Barnstead International of Thermo Fisher Scientific, Ottawa, Ontario, Canada) on the liquid setting $\left(121^{\circ} \mathrm{C}, 20 \mathrm{~Pa}\right)$ for 15 minutes. The autoclaved flasks were left to cool at room temperature.

\section{Production medium}

A specially formulated nutrient deprived amino acid rich medium was used for jadomycin B production. The composition of the production medium is shown in Table 2. The various chemical components of these medium were obtained from Fisher Scientific (Ottawa, Ontario, Canada), BioShop (Burlington, Ontario, Canada), EM Science (Lawrence, Kansas, USA) and Baker Chemical Company (Phillipsburg, New Jersey, USA). The production medium contained

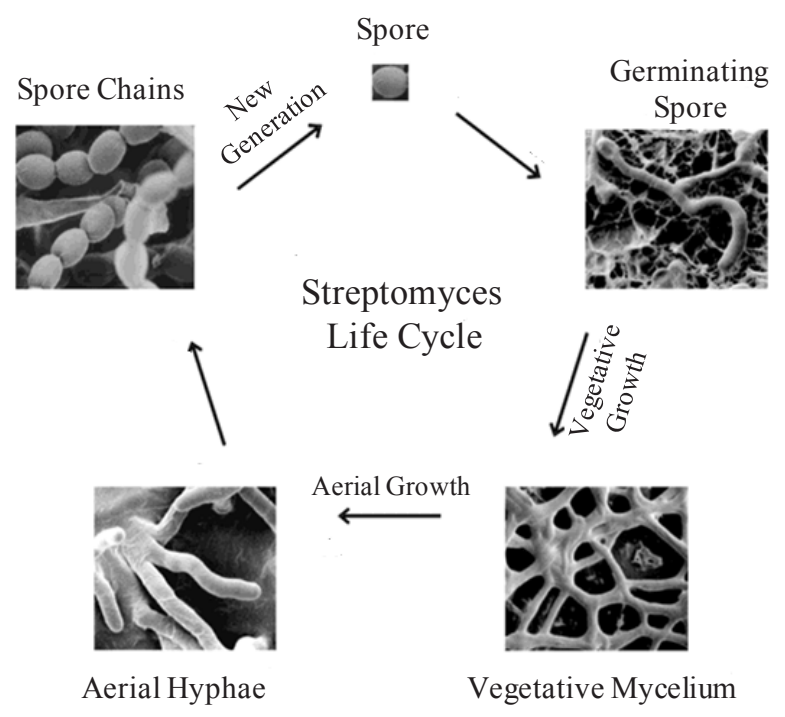

Figure 3: Life cycle of Streptomyces [31].

\begin{tabular}{lcc}
\hline Component & \multicolumn{2}{c}{ Quantity (g/L distilled water) } \\
\cline { 2 - 3 } & MYM Agar & MYM Broth \\
\hline Maltose & 4.0 & 4.0 \\
Yeast Extract & 4.0 & 4.0 \\
Malt Extract & 10.0 & 10.0 \\
MOPS & 1.9 & 1.9 \\
Agar & 15.0 & \\
\hline
\end{tabular}

Table 1: MYM agar and MYM broth media components. 
Citation: Brooks MS, Burdock TJ, Ghaly AE, Dave D (2012) Changes in Cell Structure, Morphology and Activity of Streptomyces venezuelae during the Growth, Shocking and Jadomycin Production Stages. J Microb Biochem Technol 4: 063-075. doi:10.4172/1948-5948.1000073

\begin{tabular}{lcc}
\hline Component & $\begin{array}{c}\text { Chemical } \\
\text { Formula }\end{array}$ & $\begin{array}{c}\text { Quantity } \\
\text { (per L distilled water) }\end{array}$ \\
\hline MOPS (Organic buffer) & $\mathrm{C}_{7} \mathrm{H}_{15} \mathrm{NO}_{4} \mathrm{~S}$ & $1.9 \mathrm{~g}$ \\
Salt Solution & $\mathrm{NaCl}$ & $9.0 \mathrm{~mL}$ \\
Sodium Chloride & $\mathrm{CaCl}_{2}$ & $9.0 \mathrm{~mL}$ \\
Calcium Chloride & $\mathrm{MgSO}_{4}$ & $0.4 \mathrm{~g}$ \\
Magnesium Sulfate & $\mathrm{FeSO}_{4} \cdot 7 \mathrm{H}_{2} \mathrm{O}$ & $4.5 \mathrm{~mL}$ \\
Ferrous Sulfate Solution (0.2\%) & & 10.0 \\
Trace Mineral Solution & $\mathrm{ZnSO}_{4} \cdot 7 \mathrm{H}_{2} \mathrm{O}$ & 10.0 \\
Zinc Sulfate & $\mathrm{CuSO}_{4} \cdot 5 \mathrm{H}_{2} \mathrm{O}$ & $4.5 \mathrm{~mL}$ \\
Cupric Sulfate & $\mathrm{MnSO}_{4} \cdot 4 \mathrm{H}_{2} \mathrm{O}$ & $4.5 \mathrm{~mL}$ \\
Manganese Sulfate & $\mathrm{H}_{3} \mathrm{BO}_{3}$ & $4.5 \mathrm{~mL}$ \\
Boric Acid & $\left.\mathrm{NH}_{4}\right)_{6} \mathrm{Mo}_{7} \mathrm{O}_{24} \cdot 4 \mathrm{H}_{2} \mathrm{O}$ & 4.0 \\
Ammonium Molybdate & $\mathrm{C}_{6} \mathrm{H}_{13} \mathrm{NO}_{2}$ & $0.8 \mathrm{~mL}$ \\
Isoleucine (Amino acids) & $\mathrm{C}_{6} \mathrm{H}_{12} \mathrm{O}_{6}$ & $4.5 \mathrm{~mL}$ \\
Glucose & $\mathrm{NaH}_{2} \mathrm{PO}_{4} \cdot \mathrm{H}_{2} \mathrm{O}$ & $7.8 \mathrm{~g}$ \\
Sodium Phosphate Monobasic Solution & 0.039 & 0.0061 \\
\hline
\end{tabular}

Table 2: Production medium components

aliquots from salt, ferrous sulphate, trace mineral, glucose, and phosphate stock solutions.

The stock of the salt solution was prepared by adding $5 \mathrm{~g} \mathrm{NaCl}$ and $5 \mathrm{~g} \mathrm{CaCl}_{2}$ into a $500 \mathrm{~mL}$ vessel and bringing the total volume to $500 \mathrm{~mL}$ with distilled water. The stock of ferrous sulfate solution was prepared by adding $1 \mathrm{~g} \mathrm{FeSO}_{4} \cdot 7 \mathrm{H}_{2} \mathrm{O}$ into a $500 \mathrm{~mL}$ vessel and bringing the total volume to $500 \mathrm{~mL}$. The stock of trace mineral solution was prepared by adding $880 \mathrm{mg} \mathrm{ZnSO} \cdot 7 \mathrm{H}_{2} 0,39 \mathrm{mg} \mathrm{CuSO} \cdot 5 \mathrm{H}_{2} 0,6.1 \mathrm{mg} \mathrm{MnSO} \cdot 4 \mathrm{H}_{2} \mathrm{O}$, $5.7 \mathrm{mg} \mathrm{H}_{3} \mathrm{BO}_{3}$, and $3.7 \mathrm{mg}\left(\mathrm{NH}_{4}\right)_{6} \mathrm{Mo}_{7} \mathrm{O}_{24} \cdot 4 \mathrm{H}_{2} \mathrm{O}$ into a $1 \mathrm{~L}$ vessel and bringing the total volume to $1 \mathrm{~L}$ with distilled water. A $30 \mathrm{mM}$ glucose solution was prepared by adding $5.94 \mathrm{~g}$ glucose into a $50 \mathrm{~mL}$ vessel and bringing the total volume to $20 \mathrm{~mL}$ with distilled water. The phosphate stock solution was prepared by adding $1.24 \mathrm{~g} \mathrm{NaH}_{2} \mathrm{PO}_{4} \cdot \mathrm{H}_{2} \mathrm{O}$ into a $1 \mathrm{~L}$ vessel and bringing the total volume into $1 \mathrm{~L}$ with distilled water.

An initial solution was prepared by adding $0.4 \mathrm{~g} \mathrm{MgSO}_{4}, 1.9$ g MOPS, $7.8 \mathrm{~g}$ isoleucine, $9 \mathrm{~mL}$ salt solution ( $1 \% \mathrm{w} / \mathrm{v} \mathrm{NaCl} ; 1 \% \mathrm{w} / \mathrm{v}$ $\mathrm{CaCl}_{2}$ ), $4.5 \mathrm{~mL} 0.2 \% \mathrm{FeSO}_{4} \cdot 7 \mathrm{H}_{2} \mathrm{O}$, and $4.5 \mathrm{~mL}$ trace mineral solution into a $1 \mathrm{~L}$ vessel. The total volume was brought to $1 \mathrm{~L}$ with distilled water. This solution and the glucose and phosphate solutions were autoclaved separately to avoid any precipitation. All solutions were autoclaved (SterileMax, Harvey/Barnstead International of Thermo Fisher Scientific, Ottawa, Ontario, Canada) on the liquid setting $\left(121^{\circ} \mathrm{C}, 20 \mathrm{~Pa}\right)$ for 15 minutes. Upon cooling to room temperature, $5.5 \mathrm{~mL}$ phosphate stock solution and $20 \mathrm{~mL}$ of glucose solution were added aseptically to the vessel containing the other media components of the production medium. Aliquots of $175 \mathrm{ml}$ of this medium were aseptically added to previously sterilized $250 \mathrm{~mL}$ flasks, covered with foam and aluminum foil and stored in the refrigerator until needed.

\section{Triphenyl formazan standard curve}

To determine the absorbance measured at $484 \mathrm{~nm}\left(\mathrm{AU}_{484}\right)$ corresponding to the triphenyl formazan (TF) concentration, a standard curve was developed. A TF stock solution of $0.2 \mu \mathrm{mol} / \mathrm{mL}$ was prepared by dissolving $0.03 \mathrm{~g}$ triphenyl formazan in $500 \mathrm{~mL}$ methanol. From the stock solution, a set of 11 solutions were prepared with triphenyl concentrations of $0.004 \mu \mathrm{mol} / \mathrm{mL}, 0.01 \mu \mathrm{mol} / \mathrm{mL}, 0.02 \mu \mathrm{mol} /$ $\mathrm{mL}, 0.03 \mu \mathrm{mol} / \mathrm{mL}, 0.04 \mu \mathrm{mol} / \mathrm{mL}, 0.05 \mu \mathrm{mol} / \mathrm{mL}$, the stock solution, a set of 11 solutions were prepared with triphenyl concentrations of $0.004 \mu \mathrm{mol} / \mathrm{mL}, 0.06 \mu \mathrm{mol} / \mathrm{mL}, 0.07 \mu \mathrm{mol} / \mathrm{mL}, 0.08 \mu \mathrm{mol} / \mathrm{mL}, 0.09$ $\mu \mathrm{mol} / \mathrm{mL}$, and $0.1 \mu \mathrm{mol} / \mathrm{mL}$. The absorbance of the 11 solutions were measured at a wavelength of $484 \mathrm{~nm}$. The spectrophotometer (Genesys
20, Thermo Scientific, Mississauga, Ontario, Canada) was zeroed with a blank sample of methanol. The absorbance readings were plotted against the prepared triphenyl formazan concentrations $(\mu \mathrm{mol} / \mathrm{mL})$ as shown in Figure 4. The following linear relationship between the absorbance $\left(\mathrm{AU}_{484}\right)$ and the TF was obtained $\left(\mathrm{R}^{2}=0.98\right)$.

$$
A U_{484}=10.574 T F
$$

where: $A U_{484}$ is the absorbance reading at $484 \mathrm{~nm} T F$ is the concentration of triphenyl formazan ( $\mu \mathrm{mol} / \mathrm{mL}$ extraction solvent)

\section{Streptomyces venezuelae growth on MYM agar plates}

The liquified MYM agar $(15 \mathrm{~mL})$ was aseptically poured into individual petri plates and left to solidify. After the solidification of agar, a loopful of culture from the initial starter plate of Streptomyces venezuelae ISP5230 was streaked on each petri plate using a disposable inoculation loop. The inoculated plates were incubated at $30^{\circ} \mathrm{C}$ for 48 hours until visible colonies formed. The subcultured petri plates were preserved at $4^{\circ} \mathrm{C}$ in the refrigerator until used for inoculating the liquid MYM growth media.

\section{Triphenyl formazan-CFU standard curve}

In order to determine the $\mathrm{TF}$ yield corresponding to a given number of live cells, a standard curve was established. One of the 250 $\mathrm{mL}$ flask containing $175 \mathrm{~mL}$ autoclaved MYM broth was inoculated with Streptomyces venezuelae ISP5230 from MYM agar plates. The flask was incubated in an environmentally controlled shaker (25 Incubator Shaker, New Brunswick Scientific, Edison, New Jersey, USA) at $30^{\circ} \mathrm{C}$ and $250 \mathrm{rpm}$ for 40 hours. Samples were taken at 1, 3, 10, 20, 25, 35 hours and the TTC and plate count test were performed on the samples. TF yield was plotted versus the number of CFU as shown in Figure 5.

\section{Experimental protocol}

Three of the $250 \mathrm{~mL}$ flasks containing $175 \mathrm{~mL}$ autoclaved MYM broth were inoculated with S. venezuelae ISP5230 from MYM agar plates and incubated in a controlled environmental shaker (25 Incubator Shaker, New Brunswick Scientific, Essdison, New Jersey, USA) at $30^{\circ} \mathrm{C}$ and $250 \mathrm{rpm}$. Samples were collected from the three flasks at $2,12,14,21,23,38,40,42,60$ and 64 hours after incubation and the extent of cell growth was monitored over the period of 64 hours. The optical density was measured at $600 \mathrm{~nm}$ using a spectrophotometer 


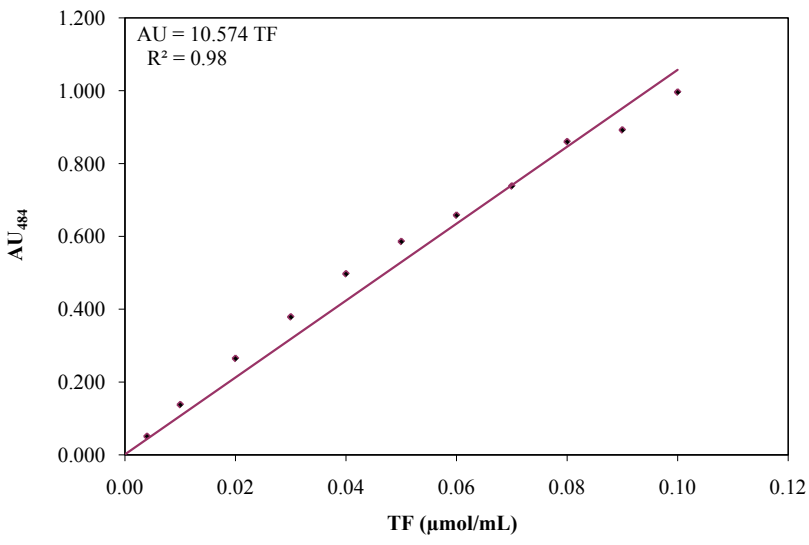

Figure 4: Triphenyl formazan yield versus absorbance .

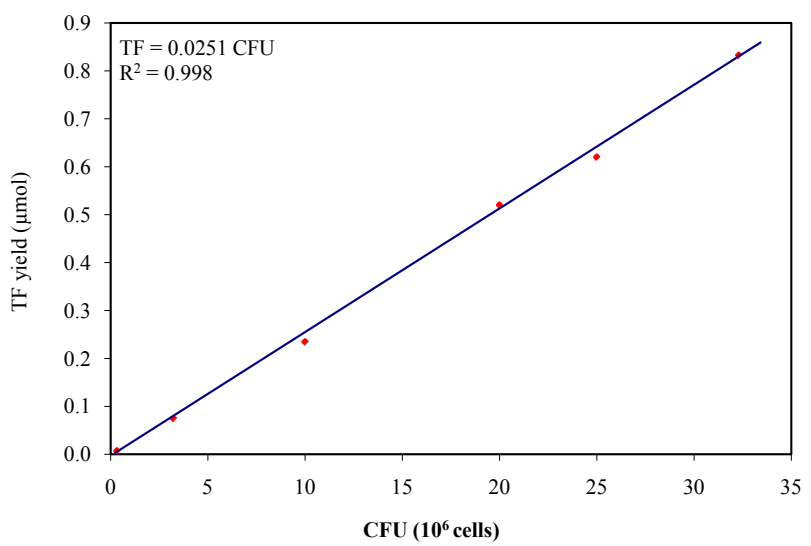

Figure 5: Triphenyl formazan yield versus CFU.

(Genesys 20, Thermo Scientific, Mississauga, Ontario, Canada) and the CFU was determined using Equation 2. The dehydrogenase activity was also determined by measuring the absorbance at $484 \mathrm{~nm}\left(\mathrm{AU}_{484}\right)$ and determining the TF yield using Equation 1. The samples collected after 40 hours of growth in the nutrient rich medium were also used for observation under the electron microscopes.

The remaining contents of the flask were used to provide cells for jadomycin B production. Three aliquots of $45 \mathrm{~mL}$ each were placed in three tubes and centrifuged (IEC CentraCL2, Thermo Electron Corporation, Mississauga, Ontario, Canada) for 10 minutes to separate cells from other media components. The supernatant was discarded and the pellet in each tube was re-suspended in $10 \mathrm{~mL}$ production medium. The resulting slurry from each tube was added to a $250 \mathrm{~mL}$ flask containing the $175 \mathrm{~mL}$ production medium. The flasks were incubated in an environmentally controlled shaker (25 Incubator Shaker, New Brunswick Scientific, Edison, New Jersey, USA) at $30^{\circ} \mathrm{C}$ and $250 \mathrm{rpm}$ for 3 hours to allow the bacteria to acclimatize to the production medium and grow. Samples were collected following the 3 hour incubation period for plate count and TTC tests and observation under the electron microscopes. After 3 hour incubation, ethanol $(100 \%)$ was added to the flasks $(3 \% \mathrm{v} / \mathrm{v})$ to shock the bacteria and start jadomycin B production. Samples were collected at 0, 8, 16, 24, 32, 48 and 72 hours after ethanol shock for plate count and observation under the electron microscopes.
Samples for jadomycin analysis were taken immediately after the ethanol shock and after 24 hours of jadomycin B production. The samples were viewed under SEM and TEM. Purified jadomycin was also viewed under SEM. The absorbance was also measured at the 526 $\mathrm{nm}\left(\mathrm{Au}_{526}\right)$ as recommended by Jakeman et al. [6].

\section{CFU determination}

A series of dilutions were carried out for the determination of the number of CFU. A $1 \mathrm{~mL}$ aliquot of the original sample was added to an autoclaved test tube containing $9 \mathrm{~mL}$ of autoclaved distilled water. The test tube was capped and inverted several times to distribute the cells. An aliquot of $1 \mathrm{~mL}$ of this solution was added to a second autoclaved test tube containing $9 \mathrm{ml}$ of autoclaved distilled water. This tube was capped and inverted to distribute the cells. This was carried out seven more times to a final dilution of $10^{-10}$. For each of the six dilutions used $\left(10^{-5}\right.$, $\left.10^{-6}, 10^{-7}, 10^{-8}, 10^{-9}, 10^{-10}\right), 0.1 \mathrm{~mL}$ was added to a petri dish containing MYM agar in triplicate (given final plate dilutions of $10^{-6}, 10^{-7}, 10^{-8}, 10$ $9,10^{-10}$, and $\left.10^{-11}\right)$. The plates were sealed with parafilm, inverted, and incubated at $30^{\circ} \mathrm{C}$ in an environmentally controlled incubator (model number 2020, VWR International, Cornelius, Oregon, USA) for 24 hours. Following the incubation period, the plates were removed and the colonies were counted. The plates that had between 30-300 CFU present were used for calculating the CFU of the samples.

\section{Dehydrogenase activity measurement}

$1 \mathrm{~mL}$ was pipetted from each sample into four test tubes. Tris buffer $(2.5 \mathrm{~mL})$ and TTC-glucose solution $(1 \mathrm{~mL})$ were added to the sample tubes $(1 \mathrm{~mL}$ of distilled water was added to the control tube). The $\mathrm{pH}$ was adjusted to 6 using $1.0 \mathrm{~N} \mathrm{HCl}$ and the test tubes were gently swirled to mix the content. The tubes were incubated in an environmentally controlled incubator (model number 2020, VWR International, Cornelius, Oregon, USA) at $30^{\circ} \mathrm{C}$ for 1 hour. The tubes were removed and centrifuged (IEC CentraCL2, Thermo Electron Corporation, Mississauga, Ontario, Canada) for 10 minutes to separate the cells from other medium components. TF extraction was carried out three times using $2.5 \mathrm{~mL}$ of methanol each time. All samples were vortexed (Thermolyne Maxi Mix, Thermolyne Corporation, Hampton, New Hampshire, USA) to disrupt cell walls and leach TF from within cells followed by centrifugation to separate the cells at the bottom. Supernatants from the three extractions were combined and the absorbance of the combined supernatants was measured at $484 \mathrm{~nm}$ (Genesys 20, Thermo Scientific, Mississauga, Ontario, Canada).

\section{Scanning electron microscope (SEM) analysis}

Each sample was filtered using medium porosity filter paper (P5, Fisher Scientific, Ottawa, Ontario, Canada) and $0.8 \mu \mathrm{m}$ filter paper (Cat. No. AAWP14250, Millipore, Billerica, MA, USA). The filter paper containing the cells was stored in a capped glass vial in the refrigerator at $4^{\circ} \mathrm{C}$ until needed for analysis. The filter paper was first dried on stubs and then coated with a gold/palladium mixture for 75 seconds to achieve a final thickness of $180 \mathrm{~nm}$. The samples were viewed using a cold field emission scanning electron microscope (S-4700, Hitachi, Mississauga, Ontario, Canada) and elemental analysis was determined using an energy dispersive spectrometer (X-Sight, Oxford Instruments, Oxfordshire, UK). Cell sizes were estimated from micrographs using scale bars. Ten cell lengths and diameters were estimated and the average value taken.

\section{Transmission electron microscopy (TEM) analysis}

Aliquots of $2 \mathrm{~mL}$ of each sample were put into a $2.0 \mathrm{~mL}$ capped test 
tubes and centrifuged in a microcentrifuge (Mini Centrifuge, Cat. No. 05-090-100, Fisher Scientific, Ottawa, Ontario, Canada) for 15 minutes. The supernatant was decanted and $1.0 \mathrm{~mL}$ of $2.5 \%$ glutaraldehyde was added to the tube. The pellet was re-suspended by gentle shaking and the tube was refrigerated at $4^{\circ} \mathrm{C}$ until needed for analysis. After a minimal fixation time of two hours in $2.5 \%$ glutaraldehyde, samples were rinsed for 10 minutes with $0.1 \mathrm{M}$ sodium cacodylate buffer three times. Samples were then fixed for two hours in $1 \%$ sodium cacodylate buffer, after which they were rinsed with distilled water. Samples were left at $4^{\circ} \mathrm{C}$ overnight in $0.25 \%$ uranyl acetate. Samples were dehydrated with a graduated series of acetone $(50 \%$ for 10 minutes, $50 \%$ for 10 minutes, $100 \%$ for 10 minutes, $70 \%$ for 10 minutes, $70 \%$ for 10 minutes, $95 \%$ for 10 minutes, $95 \%$ for 10 minutes, $100 \%$ for 10 minutes, $100 \%$ for 10 minutes and $100 \%$ for 10 minutes). Epon Araldite Resin was used to penetrate the samples in three stages: 3:1 ratio (dried 100\% acetone: Resin) for three hours, 1:3 ratio overnight, and 100\% Epon Araldite Resin for three hours. Samples were then embedded in 100\% Epon Araldite Resin and left to cure in a $60^{\circ} \mathrm{C}$ oven for 48 hours. After hardening, thin sections were cut to approximately $100 \mathrm{~nm}$ thickness using a LKB Huxley Ultramicrotome (LKB Instruments, Inc., Rockville, Maryland, USA) with a diamond knife. On a 300 mesh copper grid, samples were stained for 10 minutes with $2 \%$ aqueous uranyl acetate, rinsed twice for five minutes with distilled water, exposed to lead citrate for four minutes, rinsed again with distilled water, and left to air dry. Samples were viewed with a transmission electron microscope (FEI Tecnai-12, Philips Electron Optics, Eindhoven, Netherlands) and images were obtained with a digital camera (MegaView II, Olympus Soft Imaging Solutions, Lakewood, Colorado, USA) Cell lengths and diameters were investigated using the TEM software. Between four and seven cells were measured and the observed lengths and diameters averaged.

\section{Jadomycin purification and analysis}

Samples were filtered through five layers of medium porosity filter paper (P5, Fisher Scientific, Ottawa, Ontario, Canada) and then through $0.8 \mu \mathrm{m}$ filter paper (Cat. No. AAWP14250, Millipore, Billerica, Massachusetts, USA) to remove smaller residual media components. After filtration, the solution was passed through an isolute flash C18 chromatography column (Biotage, Charlottesville, Virginia, USA) after the column was first hydrated by rinsing it with distilled water. The components trapped in the column were removed through a series of methanol-water solutions increasing methanol concentration (10-100\% methanol). The resulting orange filtrates from the various concentrations for each methanol-water concentrations were saved in separate flasks. The solutions were then dried in a round bottom flask using a rotary evaporator (R-200, Büchi, Flawil, Switzerland) with a CryoCool unit (Neslab Instruments Inc., Portsmouth, New Hampshire, USA), dry vacuum pump (Welch, Sheboygan, Wisconsin, USA) and heating water bath (B-490, Büchi, Flawil, Switzerland). The dried solution was re-suspended in $100 \%$ methanol and trapped on silica chromatography resin. The resin containing jadomycin B was packed in a column for the final stage of purification in a biotage (SP1, Biotage, Charlottesville, Virginia, USA). The purified jadomycin, in a methanolwater solution, was dried using the rotary evaporator and the residue re-suspended in a minimal volume of $100 \%$ methanol and stored at $0^{\circ} \mathrm{C}$. Thin layer chromatography (TLC) was carried out to verify the purity of the jadomycin B. The purified jadomycin B sample was spotted on phase silica gel plates (Silicycle Inc., Quebec City, Quebec, Canada). The plates were run in DCM: $\mathrm{MeOH}: \mathrm{H}_{2} \mathrm{O}$, (95.6:4.0:0.2). The powder was viewed under the scanning electron microscope (S-4700,
Hitachi, Mississauga, Ontario, Canada). An elemental analysis was also carried out on purified jadomycin powder.

\section{Results}

\section{Morphological and structural changes}

Streptomyces venezuelae were exposed to four different environments: (a) normal growth in MYM broth (b) acclimatization to nutrient-deprived, amino acid-rich production medium (c) ethanol shock in the production medium and (d) jadomycin B production in the production medium.

\section{Growth in MYM broth}

The growth of $S$. venezuelae was determined by: (a) measuring the optical density at $600 \mathrm{~nm}\left(\mathrm{OD}_{600}\right),(\mathrm{b})$ measuring the absorbance at $484 \mathrm{~nm}\left(\mathrm{AU}_{484}\right)$ and calculating the triphenyl formazan yield (TF) from Equation 1 and (c) determining the number of colony forming units (CFU) from Equation 2. The results are presented in Figure 6. An initial lag period of 12 hours was observed followed by an exponential growth period that ended after 60 hours from the start. During the lag period, the bacteria adjusted to the new environmental condition in the growth medium and produced the enzyme required for the utilization of the substrate in the media.

After 40 hours of growth in a nutrient-rich MYM broth, $S$. venezuelae reached an average cell concentration of $2.25 \times 10^{8} \mathrm{CFU}$ per $\mathrm{mL}$ of MYM broth. This corresponded to an optical density reading at $600 \mathrm{~nm}\left(\mathrm{OD}_{600}\right)$ of 1.75 and a triphenyl formazan (TF) yield of $5.5 \mu \mathrm{mol}$ Therefore, the specific TF yield was $2.44 \times 10^{-8} \mu \mathrm{mol} / \mathrm{CFU}$.

The SEM image of cells in the sample taken after 40 hours of growth in the nutrient rich MYM broth showed a bed of filamentous hyphae (Figure 7a). The cells appeared fairly uniform (width between 0.5-1 $\mu \mathrm{m}$ ). Some strands of hyphae appeared segmented into shorter rods (approximately $2.5 \mu \mathrm{m}$ by $1 \mu \mathrm{m}$ ). Cross-sections of $S$. venezuelae hyphae are present in the TEM images (Figure $7 \mathrm{~b}$ ). Portions of vegetative hyphae that were alive and disintegrating were observed. A longitudinal cross-section of a vegetative hyphae cell $(\mathrm{H})$ with a width that varied between $0.4-0.7 \mu \mathrm{m}$ and a length of over $6 \mu \mathrm{m}$ was seen. It comprised of an electron-dense cytoplasm enclosed by a plasma membrane (PM) and cell wall (W), with a few small globular electrontransparent vacuoles (Vac) present (below $100 \mathrm{~nm}$ in width) within the cytoplasm. The globular vacuoles appear much larger (up to $800 \mathrm{~nm}$ in width) and more numerous in the other living hyphae cells pictured in Figure $7 \mathrm{~b}$, where they generally occupy the majority of the cellular volume. Rod-shaped cells (R) were observed in the TEM images, where the vacuoles either appeared distributed throughout the volume or clustered around the center. Cross walls (CW) are present within the hyphae, separating the rod-like segments. Figure $7 \mathrm{~b}$ shows a cross wall separating a living cell from a dying portion. The disintegrating hyphae cells (DC) show intracytoplasmic membranes in the form of isolated vesicles $(\mathrm{V})$ in a granular cytoplasm and the separation of the plasma membrane from the cell wall. Further disintegration of cells was evident later in the process with disruption of the outer cell wall and emptying of cytoplasm and scattering of intracellular membrane vesicles throughout the degraded cells.

\section{Acclimatization to production medium}

At the time of inoculation of the nutrient deprived-amino acid rich production medium, the optical density of $S$. venezuelae at 600 $\mathrm{nm}\left(\mathrm{OD}_{600}\right)$ was 0.805 . It reached 0.823 after 3 hours of acclimatization 
Citation: Brooks MS, Burdock TJ, Ghaly AE, Dave D (2012) Changes in Cell Structure, Morphology and Activity of Streptomyces venezuelae during the Growth, Shocking and Jadomycin Production Stages. J Microb Biochem Technol 4: 063-075. doi:10.4172/1948-5948.1000073

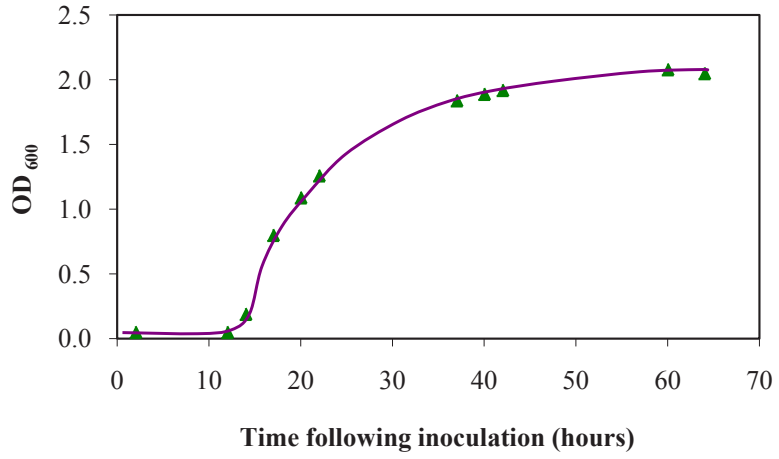

(a) Optical density

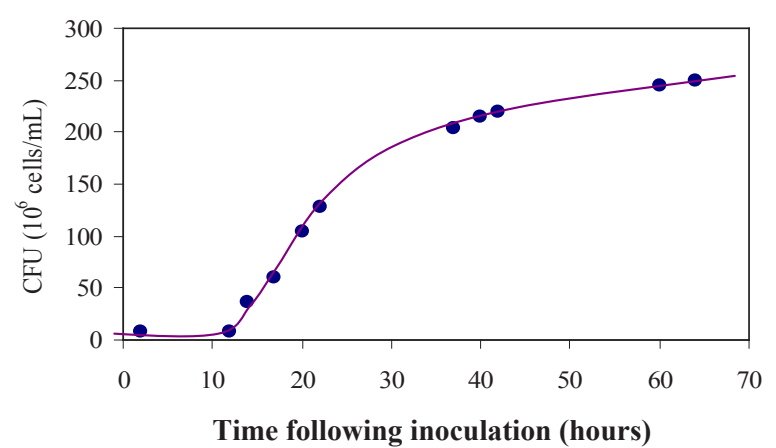

(b) $\mathrm{CFU}$

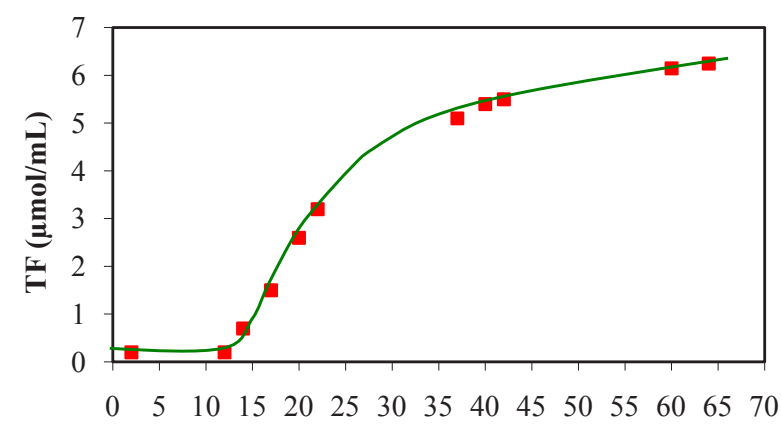

Time following inoculation (hours)

(c) TF yield

Figure 6: S. venezuelae growth in nutrient rich MYM broth as measured by optical density, CFU and TF yield.

(Figure 8). The corresponding CFU concentration in production medium was $0.9 \times 10^{8} \mathrm{cell} / \mathrm{mL}$ and the TF yield was $0.225 \mu \mathrm{mol}$. Therefore, the specific TF yield after 3 hours in the production medium was $0.25 \times 10^{-8} \mu \mathrm{mol} / \mathrm{CFU}$.

The SEM image of cells obtained 3 hours after inoculation of the production media (Figure 9a) showed a bed of filamentous hyphae. The cells did not appear uniform in width (width varied between 0.3 and $0.7 \mu \mathrm{m}$ ). Cell branching and septation were observed. Septation occurred along hyphae such that segmented chains of cells were observed with each segment having dimensions of approximately 0.4 by $0.7 \mu \mathrm{m}$ (shown with white arrows in Figure 9a). TEM images of $S$. venezuelae cells obtained 3 hours after inoculation of the production media show long hyphae $(\mathrm{H})$ with branching $(\mathrm{B})$, disintegrated cells (DC) and rod-shaped cells (R) (Figure 9b,c). Lateral circular cross- sections of thin hyphae were observed with diameters around 0.3-0.5 $\mu \mathrm{m}$. There were virtually no electron-transparent vacuoles present in the thinner (width around $0.6 \mu \mathrm{m}$ ) hyphae (Figure 9b). In the rodshaped cells (width around $0.8 \mu \mathrm{m}$ ), electron-transparent vacuoles were present and located near the center of the cells (Figure 9c). The vacuoles appeared less than $500 \mathrm{~nm}$ wide and occupied less than half of the cellular volume. Cross walls separating cells were present and rounding of the edges of the delimited cells (CW-R) was also observed.

\section{Ethanol shock in production medium}

The bacteria were shocked with ethanol after the 3 hour acclimatization period in production medium. Immediately after the ethanol shock, the optical density of $S$. venezuelae at $600 \mathrm{~nm}\left(\mathrm{OD}_{600}\right)$ remained at 0.823 with corresponding CFU of $0.9 \times 10^{8} \mathrm{CFU} / \mathrm{mL}$ and TF yield of $0.25 \mu \mathrm{mol}$. Therefore, the specific TF yield was $0.28 \times 10^{-8}$ $\mu \mathrm{mol} / \mathrm{CFU}$.

The TEM images (Figure 10a,b,c) show a similar population of cells as those observed during the acclimatization phase in the production medium. Long hyphae (H), disintegrated cells (DC) and rod-shaped cells $(\mathrm{R})$ were observed. The long hyphae (Figure 10a) shows possible sites for branching (B) and an area that appears pinched (P). The pinched area is characterized by an absence of cytoplasmic material at its narrowest part so that only the outer wall of the hyphae separate two portions of cytoplasm-rich hyphae, where each portion is greater than $2 \mu \mathrm{m}$ in length. Pinched areas also appear more frequently (Figure $10 \mathrm{~b})$, separating cytoplasmic-rich areas into areas around $1 \mu \mathrm{m}$ in length, giving each segment an ovoid appearance. New tip growth (T) is present (Figures 10b,c), where the new tips appear much thinner (around 17-30 nm) than the cells they are emerging from. Electron-

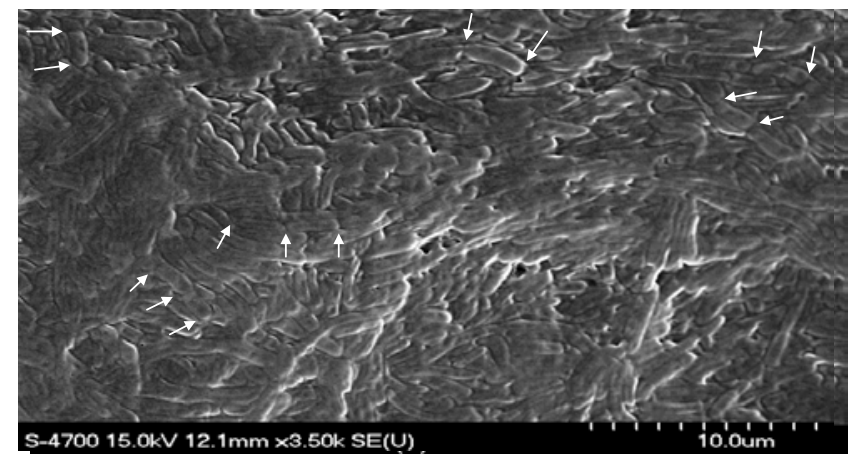

(a) SEM image of cell growth (white arrows denote ends of segmented cells)

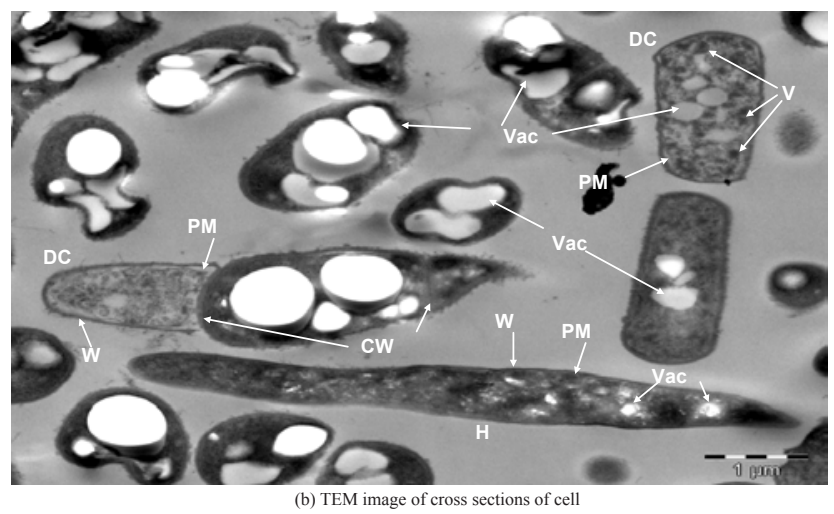

Figure 7: Micrographs of S. venezuele after 40 hours of growth in MYM broth. 
Citation: Brooks MS, Burdock TJ, Ghaly AE, Dave D (2012) Changes in Cell Structure, Morphology and Activity of Streptomyces venezuelae during the Growth, Shocking and Jadomycin Production Stages. J Microb Biochem Technol 4: 063-075. doi:10.4172/1948-5948.1000073

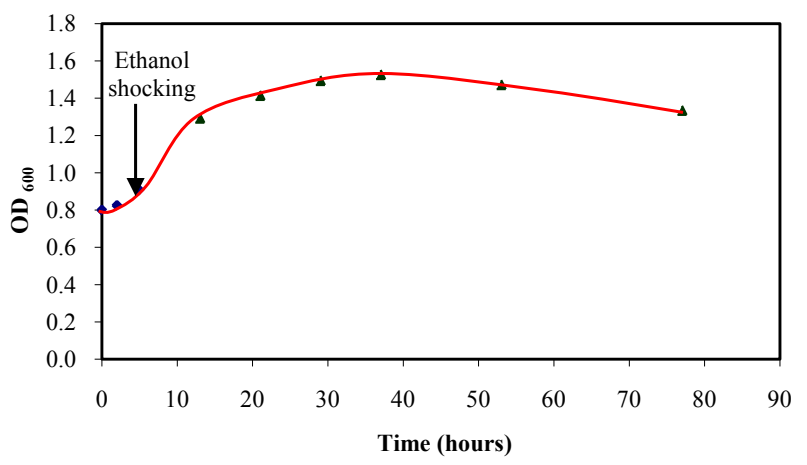

(a) Optical density

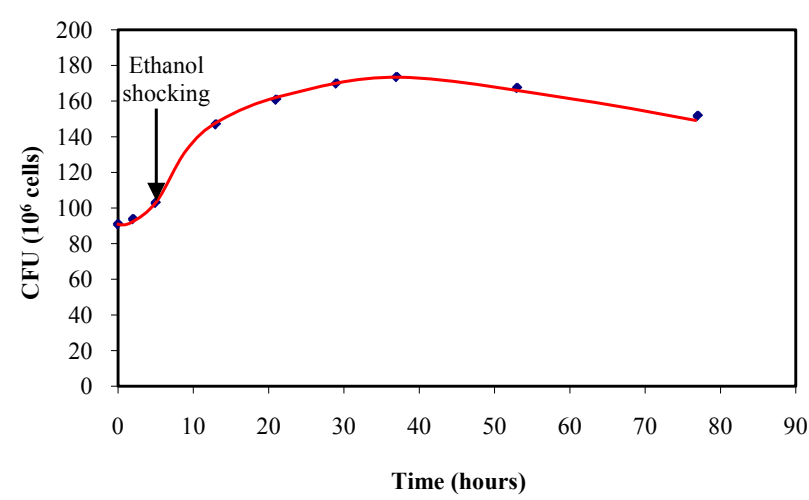

(b) $\mathrm{CFU}$

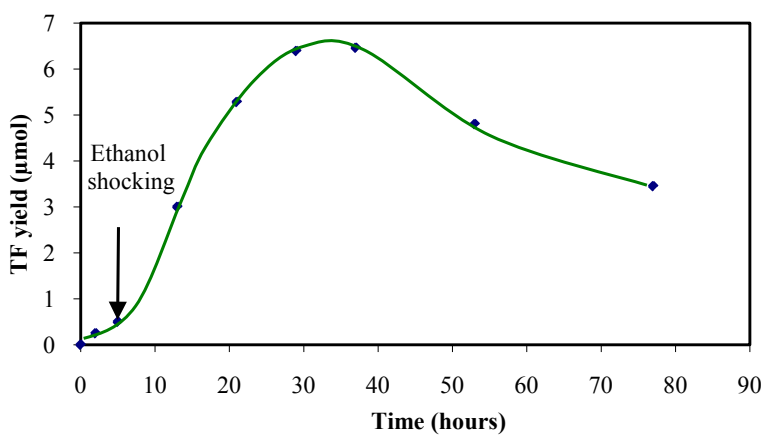

(C) TF yield

Figure 8: S. venezuelae growth in nutrient deprived - amino acid rich medium as measured by optical density, CFU and TF yield.

transparent vacuoles are sometimes present in the cells (with the sizes below $500 \mathrm{~nm}$ ), with many cells having no vacuoles present.

\section{Production of jadomycin B}

During jadomycin B production, S. venezuelae continued to grow in the production medium reaching a final optical density reading at $600 \mathrm{~nm}\left(\mathrm{OD}_{600}\right)$ of 1.335 after a period of 75 hours since ethanol shock (78 hours of production). The highest $\mathrm{OD}_{600}$ was achieved after 37 hours of production. The number of CFU increased from $0.9 \times 10^{8}$ at the time of inoculation to $1.7 \times 10^{8}$ after 40 hours and then declined to
$1.6 \times 10^{8}$ by the end of the production period (after 78 hours). The TF yield also increased from the initial value of $0.225 \mu \mathrm{mol}$ to a maximum value of $6.5 \mu \mathrm{mol}$ at the 37 hour and then declined to $3.5 \mu \mathrm{mol}$ at the end of 78 hour production period. The specific TF yield increased from the initial value of $0.25 \times 10^{-8} \mu \mathrm{mol} / \mathrm{CFU}$ to a maximum of $3.82 \times 10^{-8}$ $\mu \mathrm{mol} / \mathrm{CFU}$ at the 37 hour and then declined to $1.6 \times 10^{-8} \mu \mathrm{mol} / \mathrm{CFU}$ at the end of the 78 hour production period.

The SEM image of cells obtained 48 hours after ethanol shock in the production media (Figure 11a) showed a bed of filamentous hyphae, where most of the hyphae appeared segmented (as indicated by the white arrows highlighting segments on selected hyphae). The hyphae strands were typically segmented at intervals of $0.7 \mu \mathrm{m}$. Cell branching was also evident (B). The cells did not appear uniform in width and the majority varied between approximately 0.3 and $0.5 \mu \mathrm{m}$, although some slightly thicker cells were also present.

TEM images (Figure 11b,c,d) show long hyphae, disintegrated cells (DC) and evidence of spores (S). A germinating spore (GS) is shown, where a germ tube of $0.15 \mu \mathrm{m}$ has emerged from the spore (Figure 11b). The long hyphae cells showed branching (B) at intervals of every 0.5 $1.5 \mu \mathrm{m}$ along the main branch. However, often the branches were not fully formed and appeared as short "bud"-like protrusions. There was evidence of pinching $(\mathrm{P})$ along the hyphae, where the narrow pinched

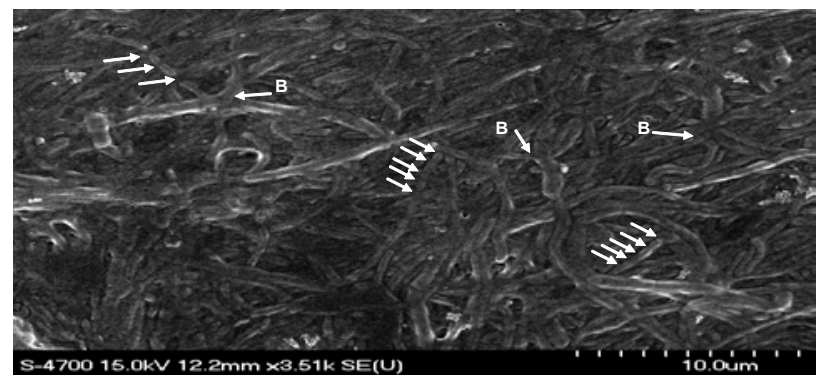

(a) SEM of cells acclimatizing to production media (white arrows show segmented chain of cells)

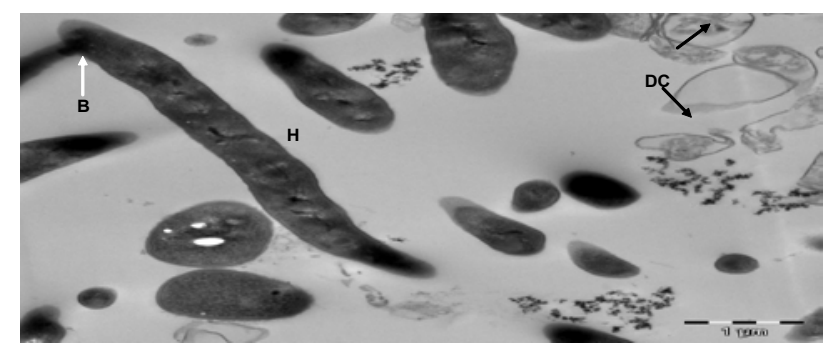

(b) TEM of cells (hyphae) acclimatizing to production media

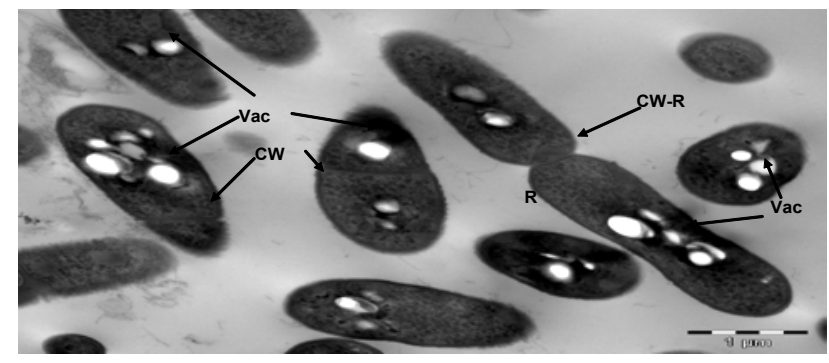

(c) TEM of cells (rod shaped) acclimatizing to production media

Figure 9: Micrographs of $S$. venezuelae taken three hours after inoculation of production medium. 
Citation: Brooks MS, Burdock TJ, Ghaly AE, Dave D (2012) Changes in Cell Structure, Morphology and Activity of Streptomyces venezuelae during the Growth, Shocking and Jadomycin Production Stages. J Microb Biochem Technol 4: 063-075. doi:10.4172/1948-5948.1000073

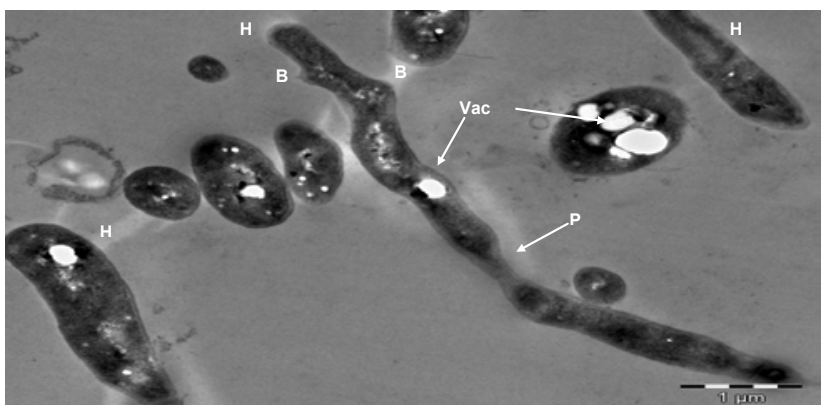

(a) TEM of cells (long hyphae) taken just after ethanol shock

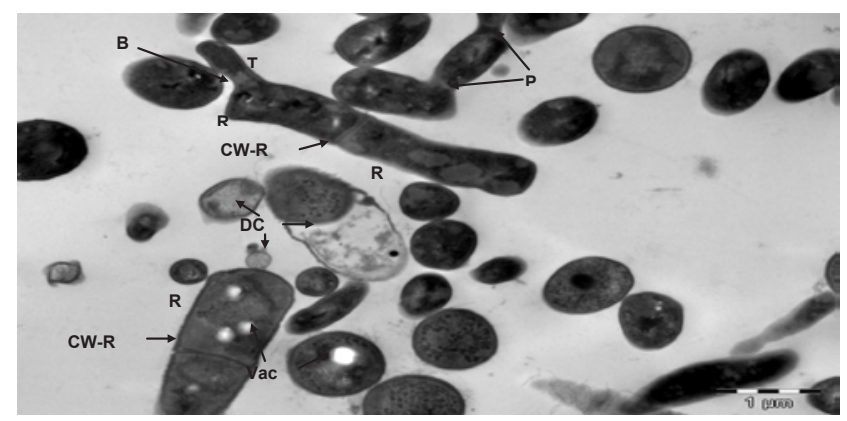

(b) TEM image of cross sections of cells showing pinched areas

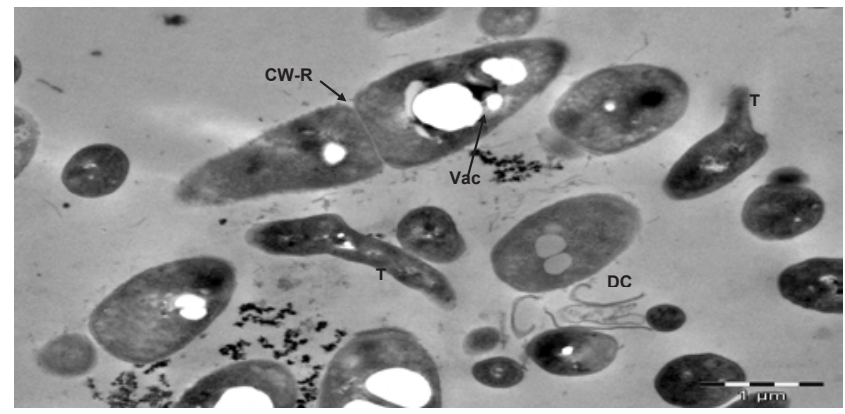

(c) TEM of cells taken just after ethanol shock showing tip growth

Figure 10: Micrographs of S. venezuelae just after ethanol shock in production medium.

regions appeared devoid of cytoplasmic material. Figure 11c shows separation of the main hyphae cell from a spore-like cell $(\mathrm{S})$, where the outer hyphal cell wall holds the spore in place. The pinched area appears flaccid, as the spore is not aligned with the cell and a budlike protrusion is evident on the main hyphal branch where the spore has separated from the main branch. Further evidence of pinching is shown in Figure 11d where the segmented regions appear to be ovoid in shape. Electron-transparent vacuoles are seen in some cells, including the long hyphae, though it is not apparent how the vacuoles are distributed overall.

\section{Jadomycin}

Jadomycin B production was monitored by measuring the absorbance at $526 \mathrm{~nm}\left(\mathrm{AU}_{526}\right)$ as suggested by Jakeman et al. [6]. Jadomycin B was successfully produced as was indicated by the increase in $\mathrm{AU}_{526}$ and the change of the colour of production medium to dark orange. Jadomycin B production stopped after 37 hours from shocking (Figure 12). There was no further increase in the $\mathrm{AU}_{526}$ after 40 hours of production ( 37 hours after shocking with ethanol). The highest $\mathrm{AU}_{526}$

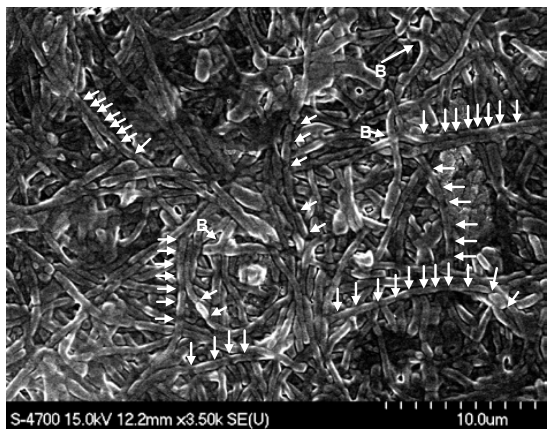

(a) SEM image of cells showing a bed of segmented hyphae

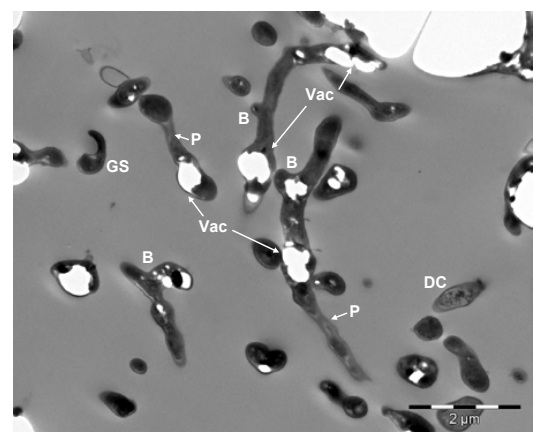

(b) TEM image of cross sections of cells showing evidence of branching vacuoles, disintegrating cells and germinating spores

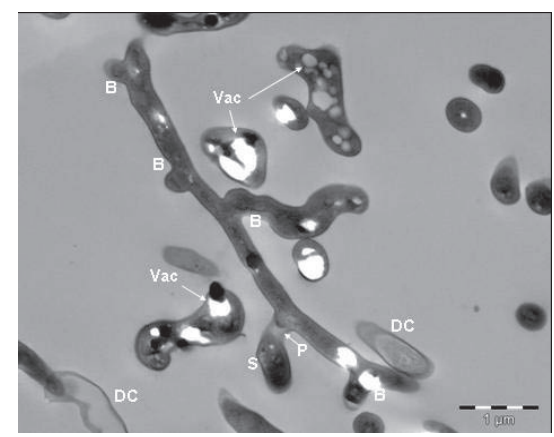

(c) TEM image of cross sections of cells showing separation of hyphae from spore cell

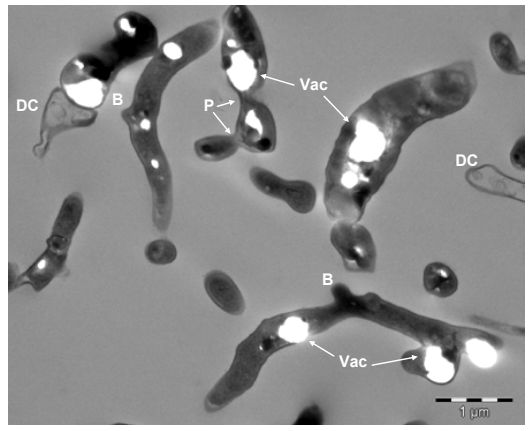

(d) TEM image of cross sections of cell showing segmented regions ovoid in like shape

Figure 11: Micrographs of $S$. venezuelae taken during jadomycin B production. 
Citation: Brooks MS, Burdock TJ, Ghaly AE, Dave D (2012) Changes in Cell Structure, Morphology and Activity of Streptomyces venezuelae during the Growth, Shocking and Jadomycin Production Stages. J Microb Biochem Technol 4: 063-075. doi:10.4172/1948-5948.1000073

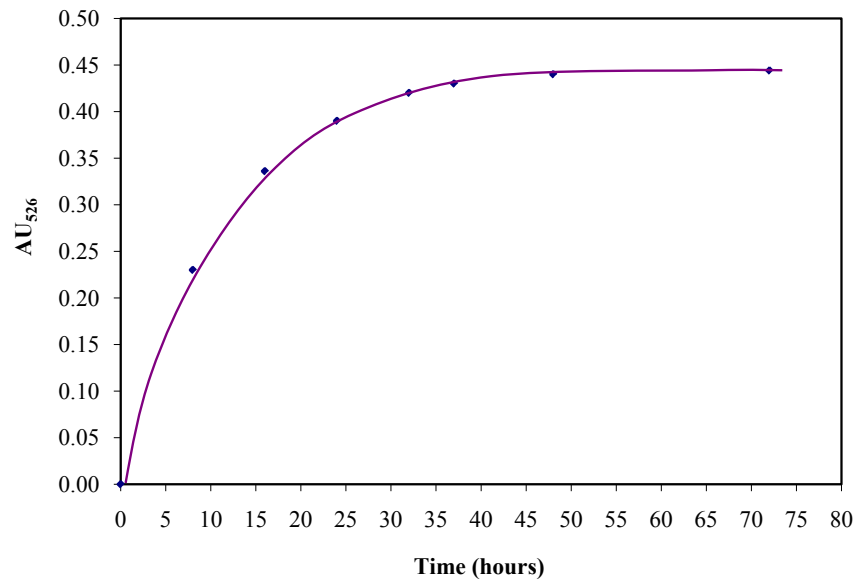

Figure 12: Jadomycin B production by S. venezuelae after ethanol shock.

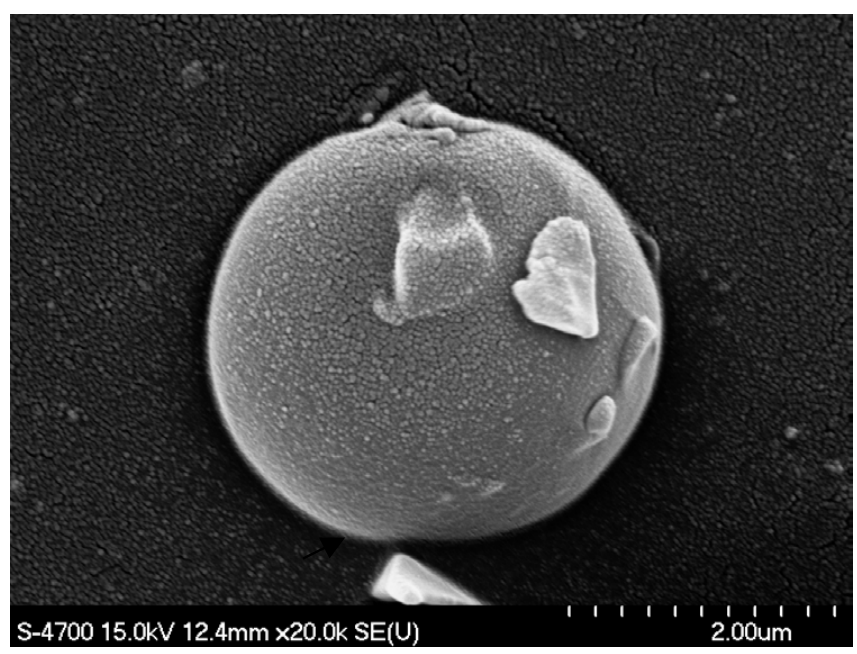

(a) Small circular particle

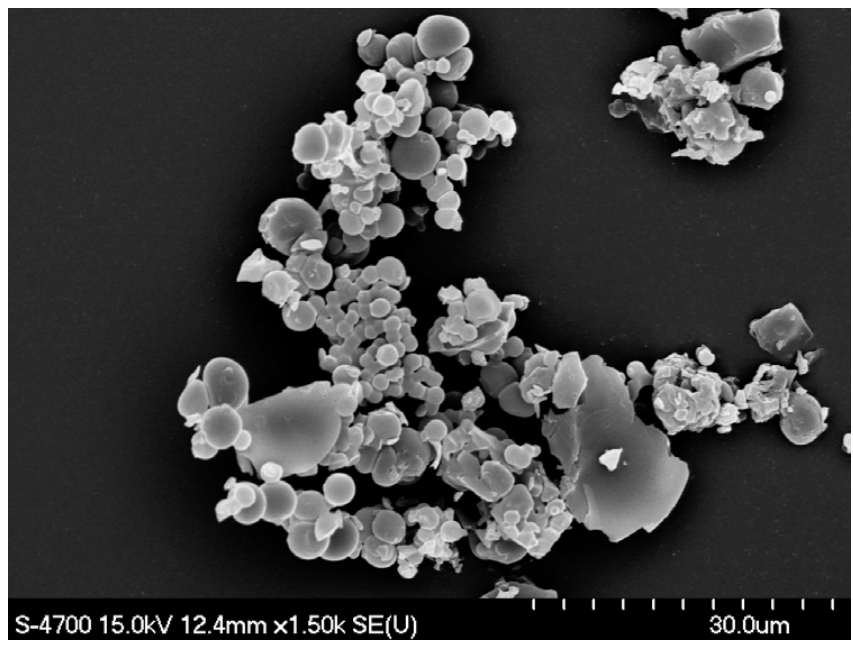

(b) Cluster of particles

Figure 13: Scanning electron microscope images of purified jadomycin B powder. was 0.418 . These results are in agreement with the highest $\mathrm{OD}_{600} \mathrm{CFU} /$ $\mathrm{mL}$ and TF yield which were obtained after 37 hour from shock with ethanol (Figure 8).

SEM images of purified jadomycin B powder (Figure 13) showed that the particles vary in size and shape. Figure 13a shows a small apparently circular piece of powder (approximately $3 \mu \mathrm{m}$ in diameter) while Figure 13b shows a larger cluster of powder (approximately 40 $\mu \mathrm{m}$ by $40 \mu \mathrm{m}$ in size), containing several particles of different shapes. The elemental analyses of the theoretical and purified jadomycin are shown in Table 3. The mean weight percentage of carbon, hydrogen, nitrogen and oxygen were $64.50 \pm 1.92,5.10 \pm 0.76,2.85 \pm 0.56$ and $22.50 \pm 1.26$, respectively. The obtained jadomycin powder appeared to have $97.95 \%$ purity.

\section{Discussion}

S. venezuelae were exposed to four different environments during the process of jadomycin production. Significant changes in the activity, structure and morphology were observed during these stages as summarized in Table 4 . These changes can be related to depletion of nutrients, shocking, and transition from vegetative cells to spore and the production of secondary metabolites. Figure 14 shows the level of cell activity as measured by the specific TF yield during growth and jadomycin B production periods.

\section{During growth in MYM broth}

S. venezuelae had the highest growth $\left(2.25 \times 10^{8} \mathrm{CFU} / \mathrm{mL}\right)$ during the growth phase in MYM broth. This was anticipated as the cells were provided with an ample supply of all nutrients required for sustained growth. The specific TF yield remained constant at $2.44 \times 10^{-8} \mu \mathrm{mol} /$ CFU during the growth period in MYM broth.

The SEM image of S. venezuelae taken during growth in the nutrientrich MYM broth showed a dense bed of filamentous hyphae. The observed cell diameter of $0.5-1.0 \mu \mathrm{m}$ is characteristic of the branching filaments from Streptomyces bacteria [13]. Bradley and Ritzi [14], reported that cross-walls are relatively rare in S. venezuelae vegetative hyphae. However, they also noted that the first step in sporogenesis is the simultaneous formation of many septa that allow the hyphae to divide into compartments, with each compartment eventually forming a spore. The segmentation via the cross-walls observed in the SEM (Figure 7a) would result in rod-like fragments of $2 \mu \mathrm{m}$ in length, which would agree with the dimensions of the spores shown by Bradley and Ritzi [14], where the length varied between 0.5 and $1.8 \mu \mathrm{m}$ with a width of $0.5-0.7 \mu \mathrm{m}$. Fragmentation of the hyphae would explain the rodlike cells that are also present in Figures $7 \mathrm{~b}, 9 \mathrm{c}$ and $10 \mathrm{~b}$ representing the stages of acclimatization to production media, ethanol shock and jadomycin production. While most actinomycetes do not sporulate in submerged culture [15] and it is considered an infrequent event [16], submerged sporulation has been observed in a number of cultures, including S. griseus [17-19], S. viridochromogenes [20], S. roseosporus [21], S. coelicolor [19,20], and S. venezuelae [16]. During the formation

\begin{tabular}{lcc}
\hline Element & Experimental Weight (\%) & Theoretical Weight (\%) \\
\hline Carbon & $64.50 \pm 1.92$ & 65.60 \\
Hydrogen & $5.10 \pm 0.76$ & 5.64 \\
Nitrogen & $2.85 \pm 0.56$ & 2.55 \\
Oxygen & $25.50 \pm 1.26$ & 26.21 \\
Others & 2.05 & \\
\hline Total & 100.00 & 100.00 \\
\hline
\end{tabular}

Table 3: Elemental analysis of jadomycin B powder. 
Citation: Brooks MS, Burdock TJ, Ghaly AE, Dave D (2012) Changes in Cell Structure, Morphology and Activity of Streptomyces venezuelae during the Growth, Shocking and Jadomycin Production Stages. J Microb Biochem Technol 4: 063-075. doi:10.4172/1948-5948.1000073

\begin{tabular}{|c|c|c|c|c|}
\hline Parameter & Growth in MYM brotha & Acclimatization in production medium ${ }^{b}$ & After ethanol shock & $\begin{array}{l}\text { During jadomycin } \\
\text { production }^{c}\end{array}$ \\
\hline $\mathrm{OD}_{600}$ & 1.750 & 0.823 & 0.823 & 1.444 \\
\hline $\mathrm{CFU} / \mathrm{mL}$ & $2.25 \times 10^{8}$ & $0.9 \times 10^{8}$ & $0.9 \times 10^{8}$ & $2.67 \times 10^{7}$ \\
\hline $\mathrm{TF}(\mu \mathrm{mol})$ & 5.5 & 0.225 & 0.250 & 0.135 \\
\hline $\mathrm{TF}(\mu \mathrm{mol} / \mathrm{CFU})$ & $2.44 \times 10^{-8}$ & $0.25 \times 10^{-8}$ & $0.28 \times 10^{-8}$ & $3.68 \times 10^{-8}$ \\
\hline Hyphae width $(\mu \mathrm{m})$ & $0.5-1$ & $0.3-0.7$ & $0.3-0.7$ & $0.3-0.5$ \\
\hline Cross walls & $\sqrt{ }$ & $\sqrt{ }$ & $\sqrt{ }$ & $\mathrm{x}$ \\
\hline Branching & $x$ & $\sqrt{ }$ & $\sqrt{ }$ & $\sqrt{ }$ \\
\hline Budding & $x$ & $x$ & $\sqrt{ }$ & $\sqrt{ }$ \\
\hline Pinching & $x$ & $x$ & $\sqrt{ }$ & $\sqrt{ }$ \\
\hline Vesicles & Large, numerous & Fewer & Fewer & Fewer \\
\hline Spore septation & $?$ & $\sqrt{ }$ & $\sqrt{ }$ & $\sqrt{ }$ \\
\hline Germinating spores & $x$ & $x$ & $?$ & $\sqrt{ }$ \\
\hline
\end{tabular}

aAfter 40 hours of growth in growth media

${ }^{b}$ After 3 hours of acclimatization in production medium

${ }^{\mathrm{c} A f t e r} 48$ hours of jadomycin production

Table 4: Changes in activity, morphology and structure of S. venezuelae during the various stages of growth and jadomycin production.

of spores in submerged culture, it has been observed that apical sections of vegetative hyphae swell developing into long, moderately swollen sporogenic hyphae, which septate and develop into chains of immature spores that mature and then separate [22].
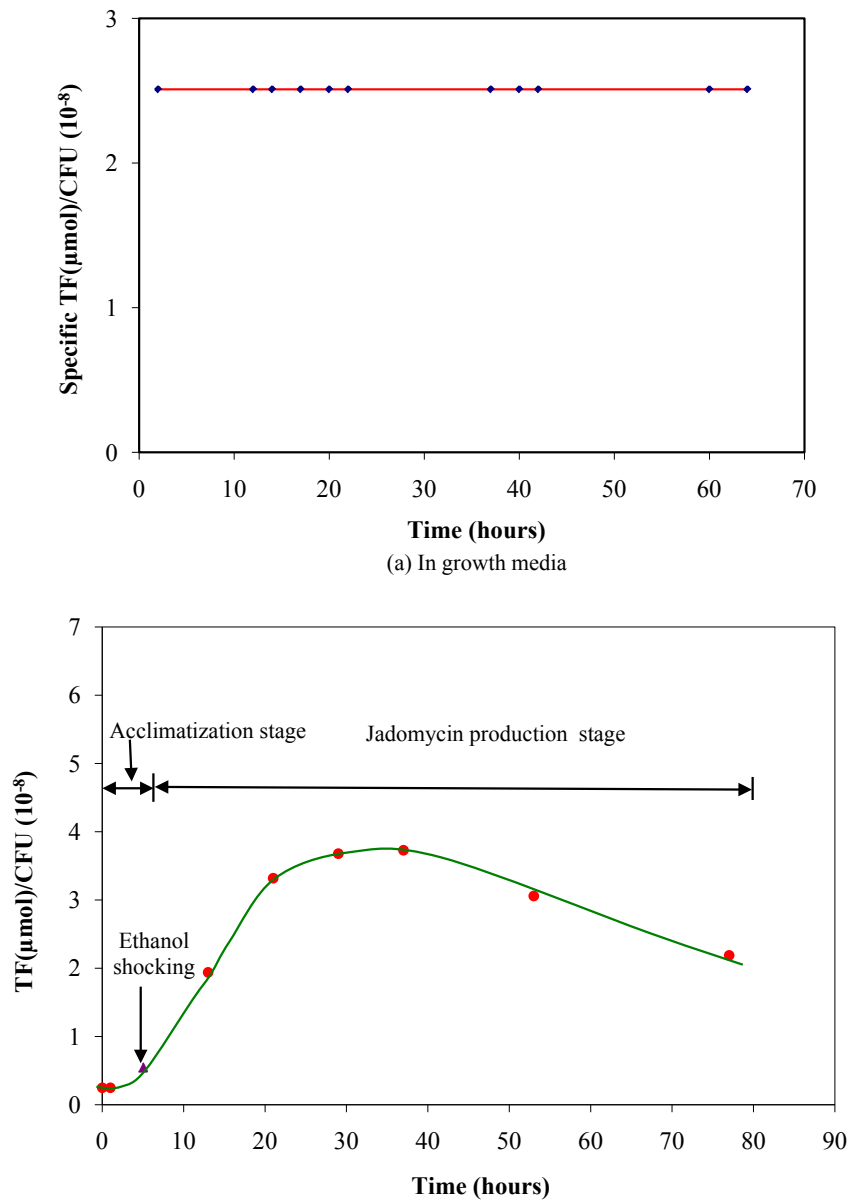

(b) In production medium

Figure 14: The activity of $S$. venezuelae as measured by specific TF yield during growth in MYM broth and production of jadomycin in production medium.
The TEM images of individual rod-like cells indicate that the longer sides of the rods were covered in a layer of amorphous material, whereas the shorter ends appeared smooth. This would support the idea that the rod-like cells were fragmented from hyphae, as the remnants of the outer component of the cell wall from the sporogenous hyphae frequently remain attached to the spore surface [14] which would correspond to the longer sides of the cell, while the shorter smooth sides would result from the newly-formed cross-walls which delimit the cells [23]. The physiological condition most often associated with spore formation is a nutritional downshift and it has been demonstrated that S. venezuelae requires nitrogen-limited conditions to sporulate [16]. At the time that the sample was taken (40 hours after inoculation of growth media), the cells were entering the stationary growth phase (Figure 6) and it is likely that cells experienced nutrient depletion that triggered spore formation.

The presence of disintegrating cells was evident in the TEM images with similar characteristics to that observed by Glauert and Hopwood [23]. Bradley and Ritzi [14], reported that in the stationary and death phases of growth, hyphal ghosts containing membranous vesicles were commonly observed during submerged cultivation. Rueda et al. [22] noted that sporogenic hyphae of S. brasiliensis growing in liquid medium consisted of two large compartments separated by a vegetative cross-wall, where the apical compartment would undergo multiple septation and subsequent development into a chair of spores, while the basal, non-sporulating compartment on the other side of the septum would degenerate and die.

The electron-transparent vacuoles present in the TEM image (Figure $7 \mathrm{~b}$ ) are similar to those observed for S. lividans by Packter and Olukoshi [24] during the late stationary growth phase, where the discrete structures were of various sizes, had no internal structure and occupied up to approximately $80 \%$ of the total cell volume at that time. They attributed the vacuoles as comprising of neutral lipids containing saturated fatty acids and while glycogen, polyhydroxybutyrate (PHB) and polyphosphates provided typical energy reserve compounds in bacteria, they reported that the accumulation of triacylglycerol (TAG) during the late stages of submerged growth was a unique characteristic of Streptomyces spp. Ranade and Vining [25], reported that small amounts of $\mathrm{PHB}$ were accumulated by $S$. venezuelae during exponential growth in media supporting chloramphenicol production, though the compound disappeared from the mycelium during the stationary growth phase. Glycogen and lipids accumulated in the mycelium during 
the stationary phase only after nitrogen was depleted, providing the principal storage compounds in S. venezuelae. The longitudinal crosssection of a hyphae cell in Figure $7 \mathrm{~b}$ appears to have very little storage material present, indicating that it is undergoing rapid growth, while the other structures which are likely cross-sections of swollen hyphae indicate that these are older hyphae with storage of TAG. Ranade and Vining [25], also noted that both glycogen and PHB were absent from spores. It is unclear whether the rod-like cells are spores or vegetative hyphae fragments. This is because multi-septation characteristic of spore formation has been observed, however the rod-like cells appear to have storage material present as vacuoles can be seen. The interpretation of Glauert and Hopwood [23], of a Streptomyces spore being a segment of hypha surrounded by a thickened hyphal wall may be useful in this case. Bradley and Ritzi [14], noted that the cell wall of a mature spore of $S$. venezuelae is around $30 \mathrm{~nm}$, whereas the cell wall in vegetative hyphae is typically around $15 \mathrm{~nm}$. It is possible that the rod-like cells may be a form of immature spore.

\section{During acclimatization to production medium}

Before the ethanol shock in the production medium, the population size was $0.9 \times 10^{8} \mathrm{CFU} / \mathrm{mL}$. The specific TF yield was relatively low $\left(0.25 \times 10^{-8} \mu \mathrm{mol} / \mathrm{CFU}\right)$ compared to that of vegetative cells grown in MYM broth.

Hyphae viewed under the SEM ranged in diameter from 0.3 to 0.7 $\mu \mathrm{m}$ which was thinner on average than that observed in the growth media. There was extensive branching and crossing of hyphae, which was not as evident in the growth media. In addition, the septation characteristic of spore formation was observed along the length of the hyphae. However, the cross-walls appeared at shorter intervals resulting in segments of $0.7 \mu \mathrm{m}$ in length rather than $2.5 \mu \mathrm{m}$. The septation and thinning of mycelia are characteristics of ageing Streptomyces [26]. The TEM images provide insight into the changes occurring within the cells during the acclimatization period. There were no vacuoles present in the long hyphae (Figure 9b), indicating that the hyphae were in a rapid growth phase, which coincides with Figure $8 \mathrm{~b}$ where the cells are just entering the exponential growth phase. The rod-shaped cells in Figure $9 \mathrm{c}$ show that the energy reserve vacuoles occupy a smaller volume within the cells and appear less numerous, which may signify a depletion of TAG, as the cells use their energy reserve to become more active metabolically in adjusting to the new environment. Figure 8b indicates that there is an increase in CFUs at this stage. As Streptomyces form CFUs from viable fragments of mycelium or outgrowths from spores [13], which indicates that the cells are actively growing. The remains of cells that have disintegrated were visible at this stage, thus the rate of cellular growth was greater than the rate of cell death.

\section{After ethanol shock}

Immediately after the administration of the ethanol shock, the $S$. venezuelae population size did not change in number and remained at $0.9 \times 10^{8} \mathrm{CFU} / \mathrm{mL}$ but the specific TF yield slightly increased from $0.25 \times 10^{-8} \mu \mathrm{mol} / \mathrm{CFU}$ to $0.28 \times 10^{-8} \mu \mathrm{mol} / \mathrm{CFU}$. Cells viewed under both the SEM and TEM appeared largely similar to the cells viewed just prior to the ethanol shock. However, there were some additional features observed. The TEM images showed pinching of vegetative hyphae, which appeared to segment the hyphae as portions of the hyphae became devoid of cytoplasmic material, resulting in "empty" flaccid regions. According to Pons et al. [26], Streptomyces tend to lose cellular content with ageing, which results in empty compartments. Segmentation by pinching seemed different from segmentation by the formation of cross-walls, as the cross-walls were typically formed between areas rich in cytoplasmic material, where the hyphae appeared turgid. In Figure 10b, the pinching appears to form a chain of sporesized cells. Bradley and Ritzi [14], reported that on solid media $S$. venezuelae developed sporulating aerial hyphae comprised of mature spores that were held in chains by a thin outer sheath. In their study of S. brasiliensis, Rueda et al. (2001) observed that sporogenic hyphae cultivated in submerged liquid media were morphologically similar to aerial hyphae and developed into chains of spores in a comparable manner

\section{During jadomycin production}

S. venezuelae population increased following the ethanol shock reaching to a maximum of $1.745 \times 10^{8} \mu \mathrm{mol} / \mathrm{CFU}$ after 32 hours, after which there was a significant decrease in population size. The TF yield followed a similar trend but the decrease in TF yield was much faster than the decrease in population size. The specific TF yield (a measure of cell activity) increased following ethanol shock and reached a maximum of $3.68 \times 10^{-8} \mu \mathrm{mol} / \mathrm{CFU}$ after 32 hours following shocking and then declined reaching $2.35 \times 10^{-8} \mu \mathrm{mol} / \mathrm{CFU}$ by the end of the experiment.

S. venezuelae produces two antibiotics choramphenicol and jadomycin, neither of which is produced in rich media [27]. Choramphenicol production is associated with nitrogen metabolism and high rates of production are observed when poorly assimilated nitrogen sources are available, which also results in a slower microbial growth rate [28]. Jadomycin is only produced when an additional stress (e.g. heat or ethanol) is applied to nutritionally unbalanced cultures [4]. One of the genes involved in jadomycin biosynthesis has also been found to affect morphological differentiation [27]. In the study by Wang and Vining [27], disruption of the gene resulted in a reduced growth rate of $S$. venezuelae during submerged cultivation and an altered growth morphology in minimal media. Also, sporulation of the mutants with the disrupted gene appeared less abundant and slower than the wild-type. In the present study, morphological differentiation of the bacteria was observed during jadomycin production. Spores are associated with this phase and it is possible that the production of jadomycin occurs as the spores are formed from the vegetative mycelia, for example during the septation process. It is interesting to observe that after the ethanol shock and during jadomycin production, septation by pinching appears more common where the septated filaments appear less turgid and the rigid-looking cross-walls that were present in cells grown in the nutrient-rich growth media are not observed.

In this present study, cells were still dividing in the production medium for up to 32 hours after ethanol shock, as the CFUs increased. This indicates that viable fragments of mycelium and/or germinating spores were present [13]. It was noted that samples taken from the production media at 32 hours after ethanol shock required greater than 48 hours of incubation for CFU development on MYM agar, whereas only 24 hours of incubation were required for samples plated from those grown in MYM broth, acclimatized to production media prior to ethanol shock and immediately after ethanol shock. It is unknown whether this delay in visible colony growth on MYM agar was the result of CFU formation from spores or from extremely stressed vegetative cells. The SEM and TEM images indicated that the vegetative cells undergoing septation and germinating spores are present within the liquid media. Therefore, it is likely that ungerminated spores are present as well. In any case, it is evident that the cells present in the sample of production media 32 hours after ethanol shock are morphologically different than the cell population present in the other samples, so it is not surprising that the time for colony formation on agar would differ. 
The optimization of the ethanol shock to maximize jadomycin is important when considering scale-up. If this process could be improved, higher jadomycin yield may be achieved in a more timely fashion. In larger volume reactors, the stress may not be uniformly applied to all cells. In this case, possible ways of improving jadomycin yield may be to (a) administer a larger ethanol shock and/or (b) administer a second shock during the production phase. However, in order to assess the efficiency of the stress application methods, it is necessary to determine when the jadomycin is produced and whether jadomycin production is associated with the stressed vegetative hyphae, the process of septation or the germination of spores. Once this is determined, strategies to increase the efficiency and improve methods for applying the environmental stress can be studied.

\section{Jadomycin}

From the results obtained in this study, it was not possible to detect jadomycin $\mathrm{B}$ within cells or cell vesicles during the production phase. It is probable that jadomycin is produced extracellularly by excreted enzymes, as opposed to intracellularly by the uptake of isoleucine and glucose, which are the media components required to produce jadomycin B molecules. It has been reported that species of the Streptomyces genus are able to metabolize many molecules, including amino acids extracellularly by hydrolytic enzymes [29]. The white pellet (white cells) observed from centrifugation of production medium during the jadomycin production phase further supports the idea that jadomycin B is produced externally to the cells, as jadomycin is a highly coloured compound. While it is possible an extracellular hydrolytic enzyme is responsible for the incorporation of isoleucine into the jadomycin B structure, Rix et al. [30] reported that no such enzyme had yet been identified. It is, therefore, possible that the cells were highly efficient at excreting the secondary metabolites. Further studies are needed to confirm either hypothesis.

The jadomycin B concentration reached a maximum and plateaued approximately 42 hours after the ethanol shock. During the production of secondary metabolites, cells are no longer using nutrients for growth but rather for the synthesis of defensive compounds. Several researchers have suggested a possible pathway for jadomycin B production involving the oxidation of the 5,6-bond on the angucycline intermediate, which then allows for the incorporation of isoleucine $[1,30]$. Dehydrogenase enzymes oxidize organic matter; therefore, it is not surprising that an increase in dehydrogenase activity was observed during the production of jadomycin $\mathrm{B}$.

The chemical formula of jadomycin $\mathrm{B}$ is $\mathrm{C}_{30} \mathrm{H}_{31} \mathrm{NO}_{9}$ with a molecular weight of $548 \mathrm{~g} / \mathrm{moL}$ [3]. The percentages of carbon, hydrogen, nitrogen and oxygen according to the chemical formula are 65.67, 5.65, 2.55 and 26.23 wt.\%, respectively. The weight percentages obtained in the study for carbon, hydrogen, nitrogen and oxygen were very close to those reported for jadomycin. The purity of jadomaycin powder was $97.95 \%$.

\section{Conclusion}

The dehydrogenase activity measurement assay was used to investigate changes in activity of $S$. venezuelae under different environmental conditions. The lowest specific TF yield $(0.25 \mathrm{x}$ $10^{-8} \mu \mathrm{mol} / \mathrm{CFU}$ ) was noted during the acclimatization period in production medium. The specific TF yield ( $\mu \mathrm{mol} / \mathrm{CFU})$ increased for the first 32 hours following the ethanol shock in production medium to a maximum yield of $3.68 \times 10^{-8}$, after which a gradual decline was observed to a final measurement of $2.35 \times 10^{-8}$ at the end of the experiment. The trend of the specific TF yield ( $\mu \mathrm{mol} / \mathrm{CFU})$ was directly related to jadomycin B production. Jadomycin B production reached a maximum about 42 hours after the ethanol shock as the cells continued to produce small amount of jadomycin few hours after the TF yield reached its maximum.

Structural changes in Streptomyces venezuelae were observed under scanning and transmission electron microscopes. After the ethanol shock was applied, the mycelia appeared thinner and septation (characteristic of sporulation) was evident resulting in chains of segmented cells with a "pinched" rather than turgid appearance. Germinating spores were also observed. Notably smaller and fewer storage vacuoles existed during the acclimatization phase and after the ethanol shock phase, indicating that cells were utilizing the storage lipids accumulated at the end of the growth phase.

The application of environmental stress (ethanol shock) is a key step in inducing the cells to produce jadomycin. Therefore, developing methods to effectively apply the stress to the cell population would maximize jadomycin production. The metabolic activity of the cells is associated with their physiology and structure. As the ethanol shock did not cause $100 \%$ of the cells to change their morphology immediately, a more effective stressing mechanism is needed to maximize jadomycin production from the cell population. The dehydrogenase activity assay for measuring the activity of Streptomyces venezuelae is an important tool that can be used to optimize the timing of ethanol shock to initiate jadomycin $B$ production and provide a quantitative measure for evaluating the success of the shock. The structural changes that were observed in the bacteria during the growth and jadomycin production phases give a qualitative measure that can be used to assess the effectiveness of the environmental stress. Thus, the dehydrogenase test and morphological observations will prove to be invaluable for designing a procedure to achieve optimal yields of the useful antibiotic.

The elemental analysis provided acceptable data for verifying jadomycin B production. However, the poor understanding of jadomycin B biosynthesis by Streptomyces venezuelae emphasizes the need for further investigation into the phenomenon responsible for forming the useful compound. Points of interest requiring further exploration are the exact mechanism of synthesis, the involvement of enzymes, and the location of the synthesis. Potential means of investigating the location of synthesis include using an isoleucine fluorescence tag and viewing cell slices under a transmission electron microscope or lysing cell membranes during the production phase to examine cell contents. A kinetic study on the uptake of glucose from the production medium may be more feasible and provide insight into how isoleucine is behaving during jadomycin B production, as both molecules are found in the chemical structure of jadomycin B. This may provide an idea as to how jadomycin B production can be optimized.

\section{Acknowledgment}

This research was supported by the National Science and Engineering Council (NSERC) of Canada. The authors are highly appreciative of the assistance and facilities provided through various laboratories at Dalhousie University. Ms. Patricia Scallion of the Institute for Material Research assisted with sample preparation for SEM, Dr. Ping Li of the Department of Biology and Ms. MaryAnn Trevors of the Department of Microbiology and Immunology assisted with sample preparation for TEM, Dr. David Jakeman and Ms. Cathy Graham of the College of Pharmacy assisted with jadomycin purification. Mr. Daniel Chevalier of the Minning Engineering Centre assisted with the analysis of jadomycin powder.

\section{References}

1. Jakeman DL, Graham CL, Reid TR. (2005) Novel and expanded jadomycins incorporating non-proteogenic amino acids. Bioorg Med Chem Lett 15: 52805283. 
Citation: Brooks MS, Burdock TJ, Ghaly AE, Dave D (2012) Changes in Cell Structure, Morphology and Activity of Streptomyces venezuelae during the Growth, Shocking and Jadomycin Production Stages. J Microb Biochem Technol 4: 063-075. doi:10.4172/1948-5948.1000073

2. Zheng JT, Rix U, Zhao L, Mattingly C, Adams V, et al. (2005) Cytotoxic activities of new jadomycin derivatives. J Antibiot 58: 405-408.

3. Burdock TJ, Giffin AH, Brooks MS, Ghaly AE (2008) Heat balance analysis during the production of jadomycin $\mathrm{C}$. American Journal of Biochemistry and Biotechnology 4: 7-18.

4. Doull JL, Singh AK, Hoare M, Ayer SW (1994) Conditions for the production of jadomycin B by Streptomyces venezuelae ISP5230: Effects of heat shock, ethanol treatment and phage infection. J Ind Microbiol 13: 120-125.

5. Jakeman DL, Bandi S, Graham CL, Reid TR, Wentzell JR, etal. (2009) Antimicrobial activities of jadomycin $B$ and structurally related analogues. Antimicrob Agent Chemother 53: 1245-1247.

6. Jakeman DL, Graham CL, Young W, Vining LC (2006) Culture conditions improving the production of jadomycin B. J Ind Microbiol Biotechnol 33: 767772.

7. Friedel JK, Molter K, Fischer WR (1994) Comparison and improvement of methods for determining soil dehydrogenase activity by using triphenyltetrazolium chloride and iodonitrotetrazolium chloride. Biology and Fertility of Soils 18: 291-296.

8. Xie J, Hu W, Pei H, Dun M, Qi F (2008) Detection of amount and activity of living algae in fresh water by dehydrogenase activity (DHA). Environ Monit Assess 146: 473-478.

9. Chander K, Brookes PC (1991) Is the dehydrogenase assay invalid as a method to estimate microbial activity in copper contaminated soils? Soil Biology and Biochemistry 23: 909-915.

10. Rogers JE, Li SW (1985) Effect of metals and other inorganic ions on soil microbial activity: Soil dehydrogenase assay as a simple toxicity test. Bull Environ Contam Toxicol 34: 858-865.

11. Yin J, Liu X, Song X (2001) A method of extraction at normal temperature for measurement of TTC-dehydrogenase activity and its application. China Water Wastewater 17: 23-25.

12. Beloti V, Barros M, de Freitas JC, Nero LA, de Souza JA, et al. (1998) Frequency of 2,3,5-triphenyltetrazolium chloride (TTC) non-reducing bacteria in pasteurized milk. Revista de Microbiologia 30: 137-140.

13. Holt GJ (1994) Bergey's Manual of Determinative Bacteriology (3rdedition), Williams and Wilkins Company, Baltimore, Maryland, USA.

14. Bradley SG, Ritzi D (1968) Composition and ultrastructure of Streptomyces venezuelae. Journal of Bacteriology 95: 2358-2364.

15. Whitaker A (1992) Actinomycetes in submerged culture. Appl Biochem Biotechnol 32: 23-35.

16. Glazebrook MA, Doull JL, Stuttard C, Vining LC (1990) Sporulation of
Streptomyces Venezuelae in submerged cultures. J Gen Microbiol 136: 581 588

17. Kendrick KE, Ensign JC (1983) Sporulation of Streptomyces griseus in submerged culture. J Bacteriol 155: 357-366.

18. Ochi K (1987) Metabolic initiation of differentiation and secondary metabolism by Streptomyces griseus: Significance of the stringent response (ppGpp) and GTP content in relation to A factor. J Bacteriol 169: 3608-3616.

19. Daza A, Martin JF, GIL JA (1988) Sporulation of several species of Streptomyces in submerged cultures. In Abstracts of the Seventh International Symposium on Biology of Actinomycetes 108.

20. Koepsel R, Ensign JC (1984) Microcycle sporulation of Streptomyces viridochromgenes. Arch Microbiol 140: 9-14

21. Huber FM, Piper RL, Mertz FP (1987) Sporulation of Streptomyces roseosporus in submerged culture. Journal of Industrial Microbiology 2: 235-241.

22. Rueda B, Miguélez EM, Hardisson C, Manzanal MB (2001) Mycelia differentiation and spore formation by Streptomyces brasiliensis in submerged culture. Can J Microbiol 47: 1042-1047.

23. Glauert AM, Hopwood DA (1961) The fine structure of Streptomyces violaceoruber (S. coelicolor) III. The walls of the mycelium and spores. J Biophys Biochem Cytol 10: 505-516.

24. Packter NM, Olukoshi ER (1995) Ultrastructural studies of neutral lipid localization in Streptomyces. Arch Microbiol 164: 420-427.

25. Ranade N, Vining LC (1993) Accumulation of intracellular carbon reserves in relation to chloramphenicol biosynthesis by Streptomyces venezuelae. Can $J$ Microbiol 39: 377-383.

26. Pons MN, Drouin JF, Louvel L, Vanhoutte B, Vivier H, et al. (1998) Physiologica investigations by image analysis. J Biotechnol 65: 3-14

27. Wang L, Vining LC (2003) Control of growth, secondary metabolism and sporulation in Streptomyces venezuelae ISP5230 by jadW (1), a member of the afs $A$ family of gamma-butyrolactone regulatory genes. Microbiology 149 1991-2004.

28. Shapiro S, Vining LC (1983) Nitrogen metabolism and chloramphenico production in Streptomyces venezuelae. Can J Microbiol 29: 1706-1714

29. Microbiology Bytes (2007) Streptomyces.

30. Rix U, Zheng J, Remsing R, Lily L, Greenwell L, et al. (2004) Dynamic structure of jadomycin B and the amino acid incorporation step of its biosynthesis. J Am Chem Soc 126: 4496-4497.

31. Kither T, Bibb MJ, Buttner MJ, Chater KF, Hopwood DA (2000) Practica Streptomyces otentics, John Innes Foundation, Norwick, UK. 